\title{
LEVEL II SCOUR ANALYSIS FOR BRIDGE 52 (CHESTH00100052) on TOWN HIGHWAY 10, crossing the SOUTH BRANCH WILLIAMS RIVER, CHESTER, VERMONT
}

Open-File Report 98-012

Prepared in cooperation with

VERMONT AGENCY OF TRANSPORTATION

and

FEDERAL HIGHWAY ADMINISTRATION

U.S. Department of the Interior

U.S. Geological Survey

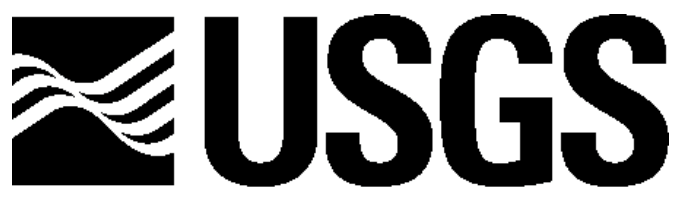

science for a changing world 


\section{LEVEL II SCOUR ANALYSIS FOR BRIDGE 52 (CHESTH00100052) on TOWN HIGHWAY 10, crossing the SOUTH BRANCH WILLIAMS RIVER, CHESTER, VERMONT \\ By EMILY C. WILD and MICHAEL A. IVANOFF}

U.S. Geological Survey Open-File Report 98-012

Prepared in cooperation with

VERMONT AGENCY OF TRANSPORTATION and

FEDERAL HIGHWAY ADMINISTRATION 


\title{
U.S. DEPARTMENT OF THE INTERIOR BRUCE BABBITT, Secretary
}

\author{
U.S. GEOLOGICAL SURVEY \\ Mark Schaefer, Acting Director
}

For additional information write to:

District Chief

U.S. Geological Survey 361 Commerce Way

Pembroke, NH 03275-3718
Copies of this report may be purchased from:

U.S. Geological Survey

Branch of Information Services

Open-File Reports Unit

Box 25286

Denver, CO 80225-0286 


\section{CONTENTS}

Conversion Factors, Abbreviations, and Vertical Datum ........................................................................ iv

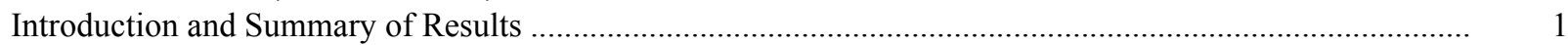

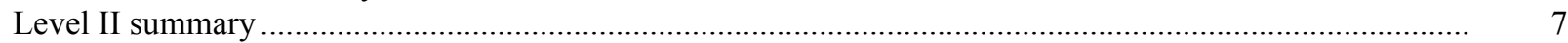

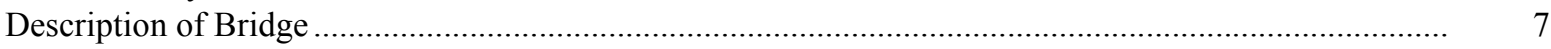

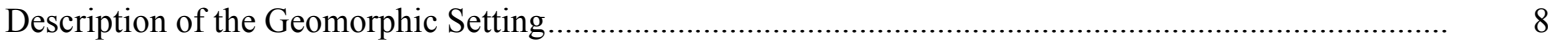

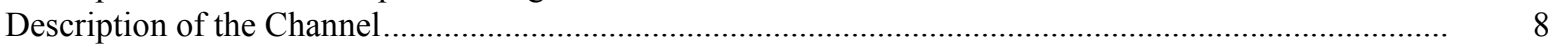

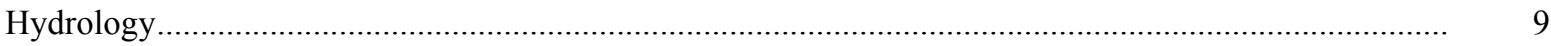

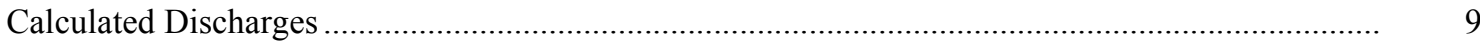

Description of the Water-Surface Profile Model (WSPRO) Analysis ........................................................ 10

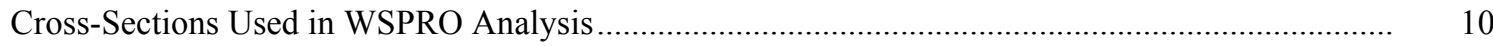

Data and Assumptions Used in WSPRO Model ............................................................................

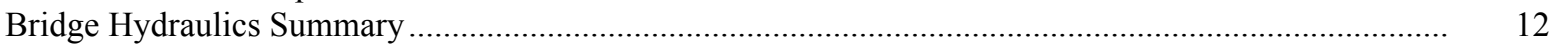

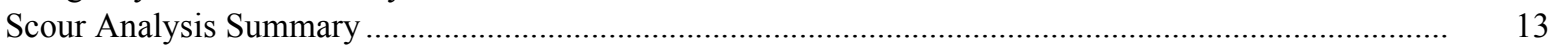

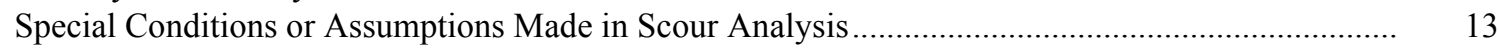

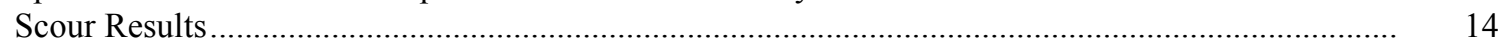

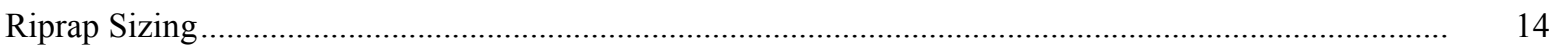

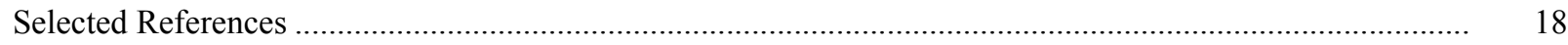

Appendices:

A. WSPRO input file

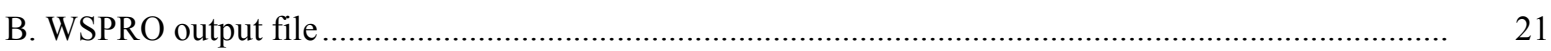

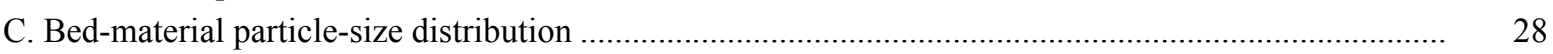

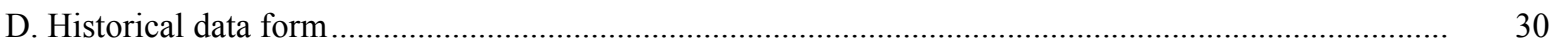

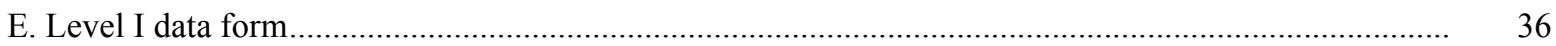

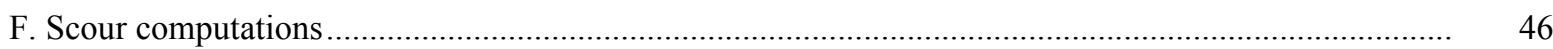

\section{FIGURES}

1. Map showing location of study area on USGS 1:25,000 scale map .........................................................

2. Map showing location of study area on Vermont Agency of Transportation town

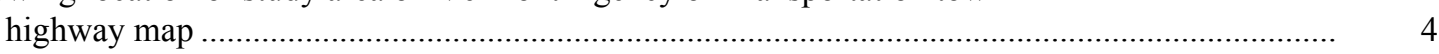

3. Structure CHESTH00100052 viewed from upstream (August 21, 1996) ………................................... 5

4. Downstream channel viewed from structure CHESTH00100052 (August 21, 1996)................................ 5

5. Upstream channel viewed from structure CHESTH00100052 (August 21, 1996)........................................ 6

6. Structure CHESTH00100052 viewed from downstream (August 21, 1996)............................................ 6

7. Water-surface profiles for the 100- and 500-year discharges at structure

CHESTH00100052 on Town Highway 10, crossing the South Branch Williams River,

Chester, Vermont.

8. Scour elevations for the 100- and 500-year discharges at structure

CHESTH00100052 on Town Highway 10, crossing the South Branch Williams River,

Chester, Vermont.

\section{TABLES}

1. Remaining footing/pile depth at abutments for the 100-year discharge at structure

CHESTH00100052 on Town Highway 10, crossing the South Branch Williams River,

Chester, Vermont

2. Remaining footing/pile depth at abutments for the 500-year discharge at structure

CHESTH00100052 on Town Highway 10, crossing the South Branch Williams River,

Chester, Vermont 


\begin{tabular}{|c|c|c|}
\hline Multiply & By & To obtain \\
\hline \multicolumn{3}{|c|}{ Length } \\
\hline inch (in.) & 25.4 & millimeter (mm) \\
\hline foot $(\mathrm{ft})$ & 0.3048 & meter $(\mathrm{m})$ \\
\hline mile (mi) & 1.609 & kilometer (km) \\
\hline \multicolumn{3}{|c|}{ Slope } \\
\hline foot per mile (ft/mi) & 0.1894 & meter per kilometer $(\mathrm{m} / \mathrm{km})$ \\
\hline \multicolumn{3}{|c|}{ Area } \\
\hline square mile $\left(\mathrm{mi}^{2}\right)$ & 2.590 & square kilometer $\left(\mathrm{km}^{2}\right)$ \\
\hline \multicolumn{3}{|c|}{ Volume } \\
\hline cubic foot $\left(\mathrm{ft}^{3}\right)$ & $\begin{array}{l}0.02832 \\
\text { Velocity and Flow }\end{array}$ & cubic meter $\left(\mathrm{m}^{3}\right)$ \\
\hline foot per second $(\mathrm{ft} / \mathrm{s})$ & 0.3048 & meter per second $(\mathrm{m} / \mathrm{s})$ \\
\hline cubic foot per second $\left(\mathrm{ft}^{3} / \mathrm{s}\right)$ & 0.02832 & cubic meter per second $\left(\mathrm{m}^{3} / \mathrm{s}\right.$ \\
\hline $\begin{array}{l}\text { cubic foot per second per } \\
\text { square mile } \\
{\left[\left(\mathrm{ft}^{3} / \mathrm{s}\right) / \mathrm{mi}^{2}\right]}\end{array}$ & 0.01093 & $\begin{array}{l}\text { cubic meter per } \\
\text { second per square } \\
\text { kilometer }\left[\left(\mathrm{m}^{3} / \mathrm{s}\right) / \mathrm{km}^{2}\right.\end{array}$ \\
\hline
\end{tabular}

\section{OTHER ABBREVIATIONS}

\begin{tabular}{|c|c|c|c|}
\hline $\mathrm{BF}$ & bank full & LWW & left wingwall \\
\hline $\mathrm{cfs}$ & cubic feet per second & Max & maximum \\
\hline $\mathrm{D}_{50}$ & median diameter of bed material & $\mathrm{MC}$ & main channel \\
\hline DS & downstream & RAB & right abutment \\
\hline elev. & elevation & RABUT & face of right abutment \\
\hline $\mathrm{f} / \mathrm{p}$ & flood plain & $\mathrm{RB}$ & right bank \\
\hline $\mathrm{ft}^{2}$ & square feet & ROB & right overbank \\
\hline $\mathrm{ft} / \mathrm{ft}$ & feet per foot & RWW & right wingwall \\
\hline FEMA & Federal Emergency Management Agency & $\mathrm{TH}$ & town highway \\
\hline FHWA & Federal Highway Administration & UB & under bridge \\
\hline JCT & junction & US & upstream \\
\hline LAB & left abutment & USGS & United States Geological Survey \\
\hline LABUT & face of left abutment & VTAOT & Vermont Agency of Transportation \\
\hline LB & left bank & WSPRO & water-surface profile model \\
\hline LOB & left overbank & yr & year \\
\hline
\end{tabular}

In this report, the words "right" and "left" refer to directions that would be reported by an observer facing downstream. Sea level: In this report, "sea level” refers to the National Geodetic Vertical Datum of 1929-- a geodetic datum derived from a general adjustment of the first-order level nets of the United States and Canada, formerly called Sea Level Datum of 1929.

In the appendices, the above abbreviations may be combined. For example, USLB would represent upstream left bank. 


\title{
LEVEL II SCOUR ANALYSIS FOR BRIDGE 52 (CHESTH00100052) ON TOWN HIGHWAY 10, CROSSING THE SOUTH BRANCH WILLIAMS RIVER, CHESTER, VERMONT
}

\author{
By Emily C. Wild and Michael A. Ivanoff
}

\section{INTRODUCTION AND SUMMARY OF RESULTS}

This report provides the results of a detailed Level II analysis of scour potential at structure CHESTH00100052 on Town Highway 10 crossing the South Branch Williams River, Chester, Vermont (figures 1-8). A Level II study is a basic engineering analysis of the site, including a quantitative analysis of stream stability and scour (FHWA, 1993). Results of a Level I scour investigation also are included in appendix $\mathrm{E}$ of this report. A Level I investigation provides a qualitative geomorphic characterization of the study site. Information on the bridge, gleaned from Vermont Agency of Transportation (VTAOT) files, was compiled prior to conducting Level I and Level II analyses and is found in appendix D.

The site is in the New England Upland section of the New England physiographic province in southeastern Vermont. The $4.05-\mathrm{mi}^{2}$ drainage area is in a predominantly rural and forested basin. In the vicinity of the study site, the surface cover is forest upstream and downstream of the bridge.

In the study area, the South Branch Williams River has an incised, sinuous channel with a slope of approximately $0.03 \mathrm{ft} / \mathrm{ft}$, an average channel top width of $35 \mathrm{ft}$ and an average bank height of 4 $\mathrm{ft}$. The channel bed material ranges from gravel to boulders with a median grain size $\left(\mathrm{D}_{50}\right)$ of $82.1 \mathrm{~mm}(0.269 \mathrm{ft})$. The geomorphic assessment at the time of the Level I and Level II site visit on August 21, 1996, indicated that the reach was unstable, as a result of the moderate bank erosion.

The Town Highway 10 crossing of the South Branch Williams River is a 32-ft-long, one-lane bridge consisting of a 29-foot steel-stringer span (Vermont Agency of Transportation, written communication, March 31, 1995). The opening length of the structure parallel to the bridge face is $27.6 \mathrm{ft}$. The bridge is supported by vertical, concrete abutments with wingwalls. The channel is skewed approximately 25 degrees to the opening while the opening-skew-to-roadway is 20 degrees. 
A scour hole $1.0 \mathrm{ft}$ deeper than the mean thalweg depth was observed at the downstream end of the right abutment during the Level I assessment. The only scour protection measure at the site was type-2 stone fill (less than 36 inches diameter) along the upstream left and right banks, the upstream end of the upstream right wingwall and the entire base length of the upstream left wingwall. Additional details describing conditions at the site are included in the Level II Summary and appendices D and E.

Scour depths and recommended rock rip-rap sizes were computed using the general guidelines described in Hydraulic Engineering Circular 18 (Richardson and Davis, 1995) for the 100- and 500-year discharges. In addition, the incipient roadway-overtopping discharge was determined and analyzed as another potential worst-case scour scenario. Total scour at a highway crossing is comprised of three components: 1) long-term streambed degradation; 2) contraction scour (due to accelerated flow caused by a reduction in flow area at a bridge) and; 3 ) local scour (caused by accelerated flow around piers and abutments). Total scour is the sum of the three components. Equations are available to compute depths for contraction and local scour and a summary of the results of these computations follows.

Contraction scour for all modelled flows ranged from 0.0 to $0.8 \mathrm{ft}$. The worst-case contraction scour occurred at the 500-year discharge. Abutment scour ranged from 5.2 to $10.8 \mathrm{ft}$. The worst-case abutment scour also occurred at the 500-year discharge. Additional information on scour depths and depths to armoring are included in the section titled "Scour Results". Scoured-streambed elevations, based on the calculated scour depths, are presented in tables 1 and 2. A cross-section of the scour computed at the bridge is presented in figure 8. Scour depths were calculated assuming an infinite depth of erosive material and a homogeneous particle-size distribution.

It is generally accepted that the Froehlich equation (abutment scour) gives "excessively conservative estimates of scour depths" (Richardson and Davis, 1995, p. 46). Usually, computed scour depths are evaluated in combination with other information including (but not limited to) historical performance during flood events, the geomorphic stability assessment, existing scour protection measures, and the results of the hydraulic analyses. Therefore, scour depths adopted by VTAOT may differ from the computed values documented herein. 


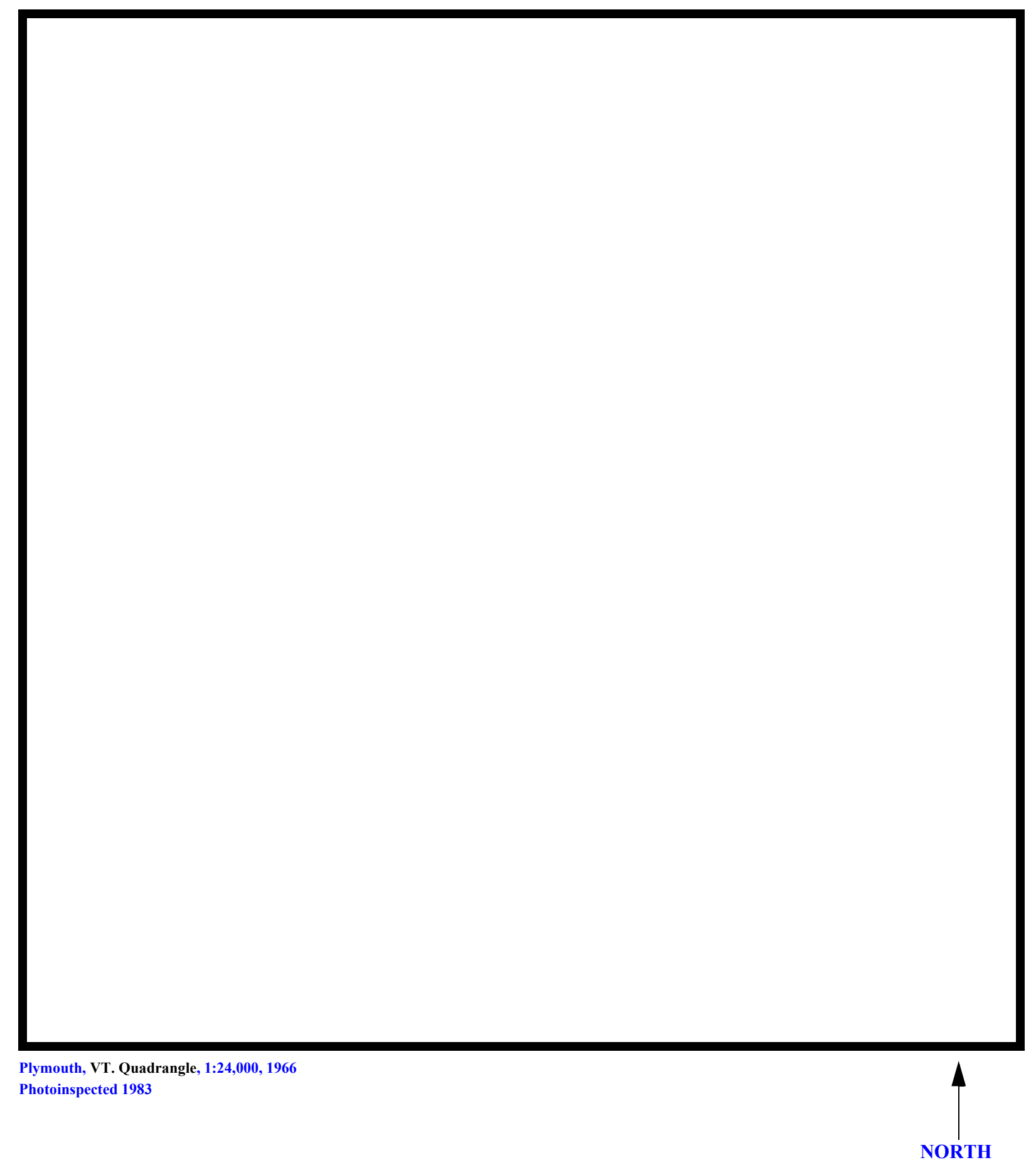

Figure 1. Location of study area on USGS 1:24,000 scale map. 
Figure 2. Location of study area on Vermont Agency of Transportation town highway map. 

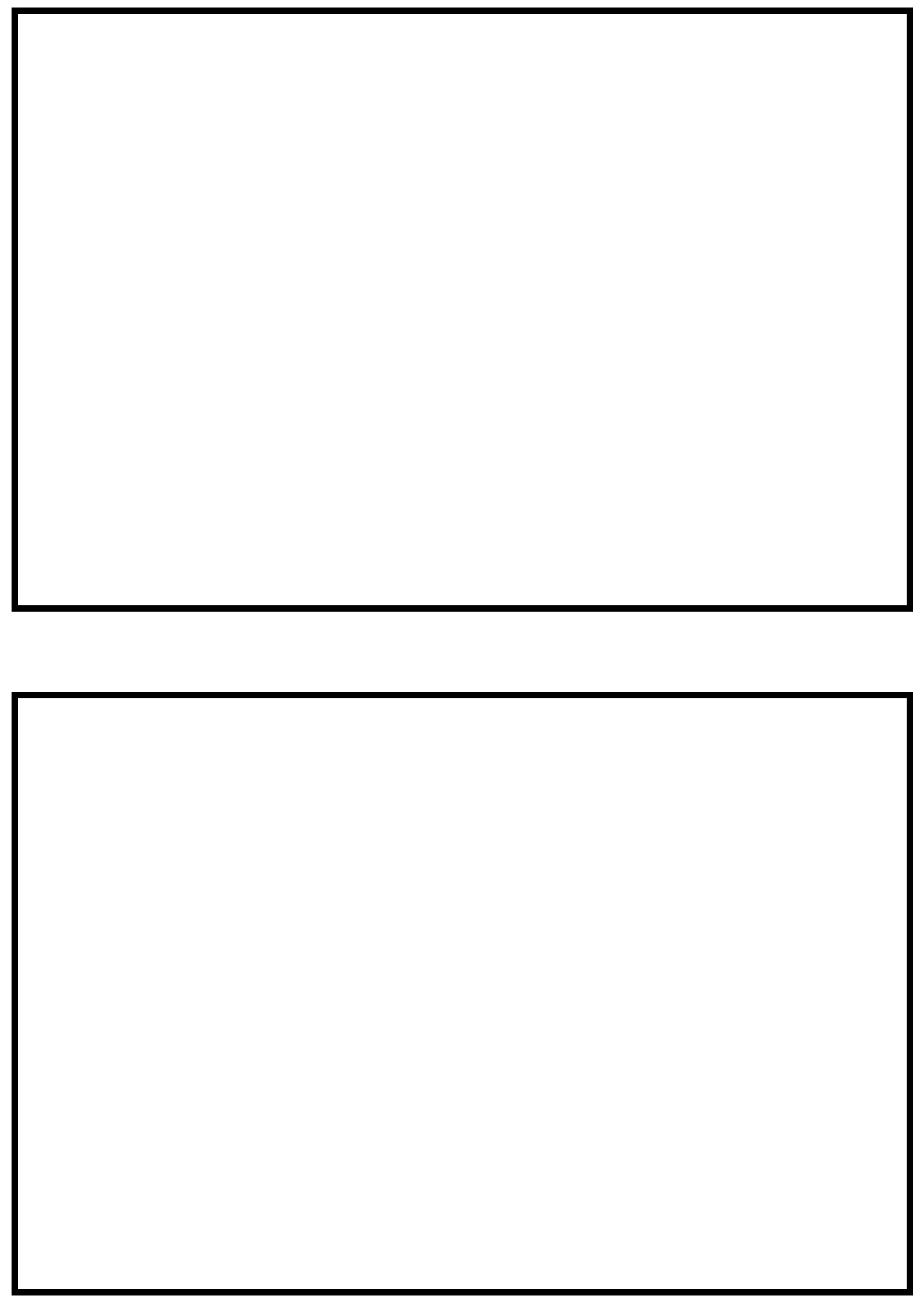

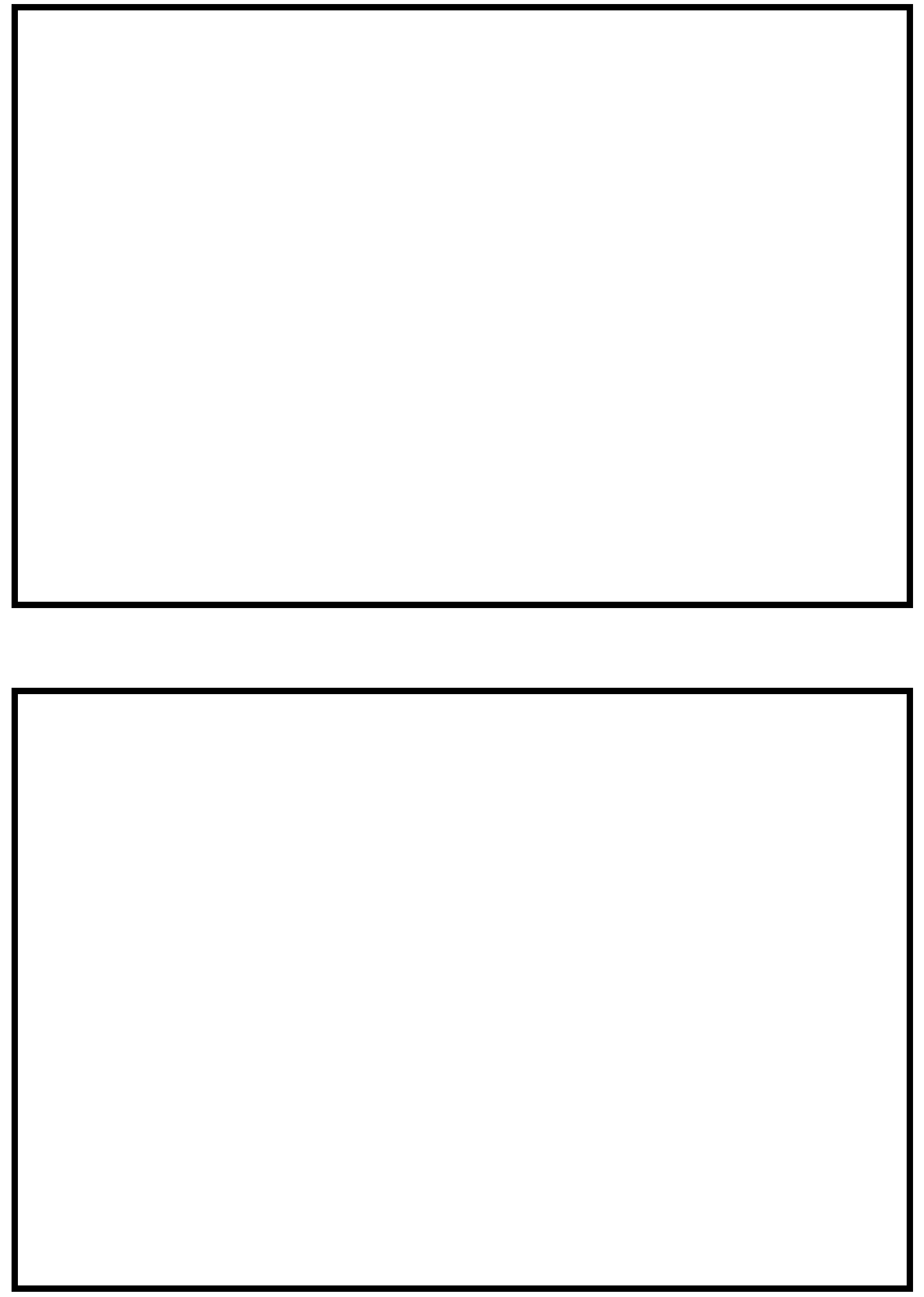


\section{LEVEL II SUMMARY}

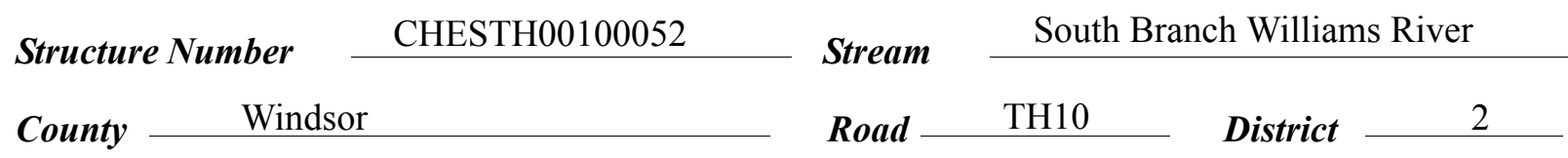

\section{Description of Bridge}

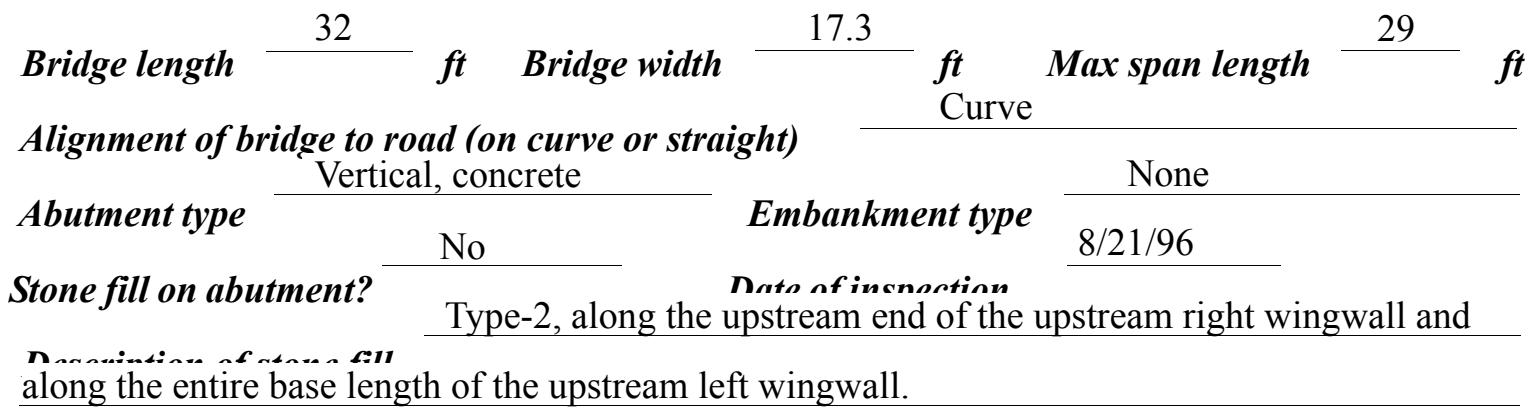

Abutments the upstream right wingwall are concrete.

There is a one foot deep scour hole in front of the downstream end of the right abutment.

Yes

\section{5 \\ Yes}

Angle

Is bridge skewed to flood flow according to There ' survey?

is a moderate channel bend in the upstream reach. The sçour hole has developed in the location

where the flow impacts the downstream end of the right abutment.

Debris accumulation on bridge at time of Level I or Level II site visit:

\begin{tabular}{|c|c|c|c|}
\hline & $\begin{array}{c}\text { Date of insnortion } \\
8 / 21 / 96 \\
\end{array}$ & $\begin{array}{l}\text { Percent of abmunal } \\
\text { blocked inortzontatly }\end{array}$ & $\begin{array}{l}\text { Percent of } 0 \\
\text { blocked verticatty }\end{array}$ \\
\hline & $8 / 21 / 96$ & 0 & 0 \\
\hline
\end{tabular}

Level II

Moderate. There is some debris along the banks and trees are

leaning over the channel upstream.

Potential for debris

None, 8/21/96.

Doscriho anv, fonturos noar ar at tho hridoo that mav, affort flou, (includo ahsorvation dato) 


\section{Description of the Geomorphic Setting}

General topography The channel is located within a moderate relief valley with little or no

flood plains.

Geomorphic conditions at bridge site: downstream (DS), upstream (US)

Date of inspection $\quad 8 / 21 / 96$

DS left: $\quad$ Moderately sloped overbank.

DS right: $\quad$ Moderately sloped overbank to a steep valley wall.

US left: $\quad$ Moderately sloped overbank.

US right: $\quad$ Steep valley wall.

\section{Description of the Channel}

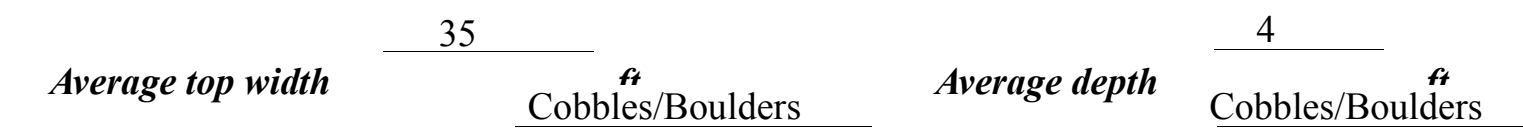

Predominant bed material

Bank material Sinuous with non-

âlluvial channél boundaries.

. . . . . . .

$8 / 21 / 96$

Vegetative co 1 Trees

DS left: $\quad$ Trees

DS right: Trees

US left: $\quad$ Trees

US right: $\quad$ No

Do banks appear stable? There are cut-banks, upstream and downstream of the bridge date of observation.

None, $8 / 21 / 96$.

Describe any obstructions in channel and date of observation. 


\title{
Hydrology
}

Drainage area $\stackrel{4.05}{\mathrm{mi}^{2}}$

Percentage of drainage area in physiographic provinces: (approximate)

Physiographic province/section New England/New England Upland
Percent of drainage area 100

\begin{abstract}
Is drainage area considered rural or urban?
Rural None.

urbanization:

Describe any significant
\end{abstract}

Is there a USGS gage on the stream of interest?

No

USGS gage description

USGS gage number

Gage drainage area $\mathrm{mi}^{2}$

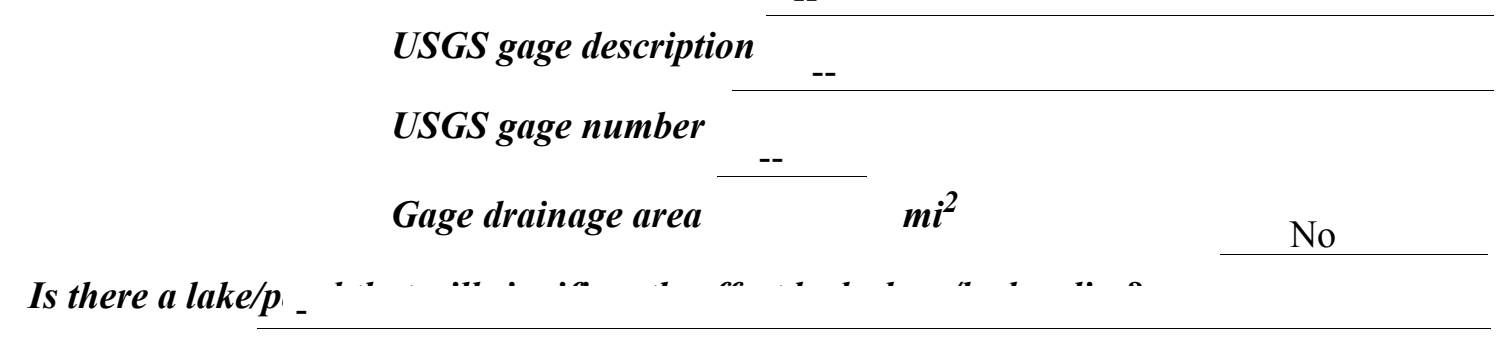

\begin{tabular}{llll}
1,550 & \multicolumn{2}{c}{ Calculated Discharges } & 2,200 \\
& $f t^{3} / \mathrm{s}$ & $\mathbf{Q 5 0 0}$ & $f t^{3} / \mathrm{s}$
\end{tabular}

The 100-year discharge is from the flood frequency

estimates available from the VTAOT database. The 500-year discharge was extrapolated graphically from these estimates. The values used were within a range defined by flood frequency curves developed from several empirical methods (Benson, 1962; Johnson and Tasker, 1974; FHWA, 1983; Potter, 1957a\&b; Talbot, 1887). 


\section{Description of the Water-Surface Profile Model (WSPRO) Analysis}

Datum for WSPRO analysis (USGS survey, sea level, VTAOT plans)

USGS survey

Datum tie between USGS survey and VTAOT plans

None

Description of reference marks used to determine USGS datum. $\quad$ RM1 is a chiseled X on top of the upstream end of the right abutment (elev. $498.88 \mathrm{ft}$, arbitrary survey datum). RM2 is a chiseled X on top of the downstream end of the right abutment (elev. $498.62 \mathrm{ft}$, arbitrary survey datum). RM3 is a chiseled X on top of the upstream end of the left abutment (elev. $500.15 \mathrm{ft}$, arbitrary survey datum).

\section{Cross-Sections Used in WSPRO Analysis}

\begin{tabular}{cccl}
\hline${ }^{1}$ Cross-section & $\begin{array}{c}\text { Section } \\
\text { Reference } \\
\text { Distance } \\
\text { (SRD) } \text { in feet }\end{array}$ & $\begin{array}{c}{ }^{2} \text { Cross-section } \\
\text { development }\end{array}$ & \multicolumn{1}{c}{ Comments } \\
\hline EXIT1 & -27 & 1 & $\begin{array}{l}\text { Exit section } \\
\text { Downstream Full-valley } \\
\text { section (Templated from } \\
\text { EXIT1) }\end{array}$ \\
BRIDG & 0 & 2 & $\begin{array}{l}\text { Bridge section } \\
\text { Road Grade section }\end{array}$ \\
RDWAY & 0 & 1 & $\begin{array}{l}\text { Modelled Approach sec- } \\
\text { tion (Templated from } \\
\text { APPR1 }\end{array}$ \\
& 11 & 1 & $\begin{array}{l}\text { APTEM) } \\
\text { Approach section as sur- } \\
\text { veyed (Used as a tem- } \\
\text { plate) }\end{array}$ \\
\hline
\end{tabular}

${ }^{1}$ For location of cross-sections see plan-view sketch included with Level I field form, Appendix E. For more detail on how cross-sections were developed see WSPRO input file. 


\section{Data and Assumptions Used in WSPRO Model}

Hydraulic analyses of the reach were done by use of the Federal Highway Administration's WSPRO step-backwater computer program (Shearman and others, 1986, and Shearman, 1990). The analyses reported herein reflect conditions existing at the site at the time of the study. Furthermore, in the development of the model it was necessary to assume no accumulation of debris or ice at the site. Results of the hydraulic model are presented in the Bridge Hydraulic Summary, appendix B, and figure 7.

Channel roughness factors (Manning's " $n$ ") used in the hydraulic model were estimated using field inspections at each cross section following the general guidelines described by Arcement and Schneider (1989). Final adjustments to the values were made during the modelling of the reach. Channel " $n$ " values for the reach were 0.065 , and overbank " $n$ " values ranged from 0.065 to 0.070 .

Normal depth at the exit section (EXIT1) was assumed as the starting water surface. This depth was computed by use of the slope-conveyance method outlined in the user's manual for WSPRO (Shearman, 1990). The slope used was $0.0283 \mathrm{ft} / \mathrm{ft}$, which was estimated from the 100-year discharge water surface slope downstream of the bridge in the Flood Insurance Study for Chester, VT (FEMA, February 1982).

The surveyed approach section (APTEM) was moved along the approach channel slope $(0.0474 \mathrm{ft} / \mathrm{ft})$ to establish the modelled approach section (APPR1), one bridge length upstream of the upstream face as recommended by Shearman and others (1986). This location also provides a consistent method for determining scour variables.

For the incipient-overtopping discharge, WSPRO assumes critical depth at the bridge section. A supercritical model was developed for this discharge. After analyzing both the supercritical and subcritical profiles, it was determined that the water surface profile does pass through critical depth within the bridge opening. Thus, the assumption of critical depth at the bridge is a satisfactory solution. 


\section{Bridge Hydraulics Summary}

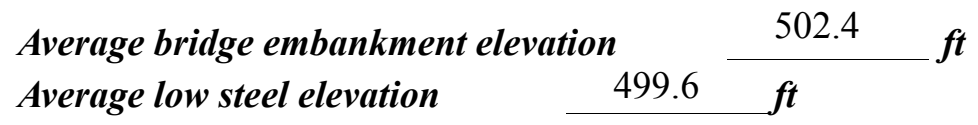

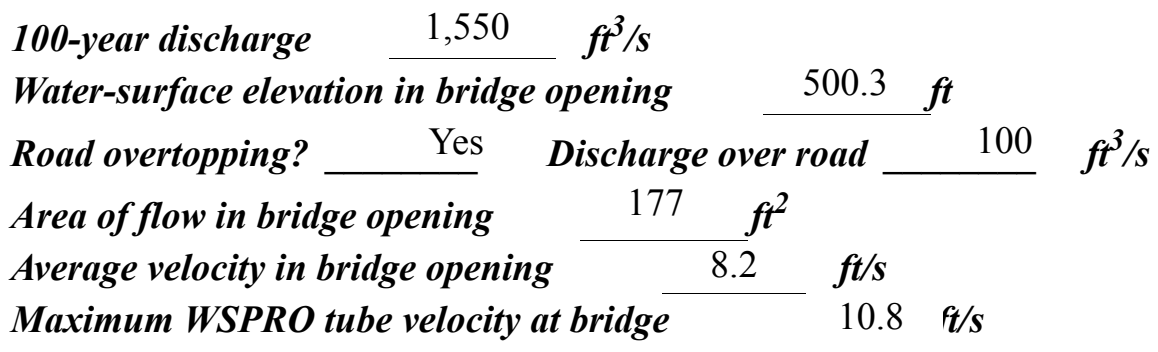

Water-surface elevation at Approach section with bridge 501.4

Water-surface elevation at Approach section without bridge $\quad 4.58$

Amount of backwater caused by bridge

2.9 it

500-year discharge $\quad 2,200 \quad \mathrm{ft}^{3} / \mathrm{s}$

Water-surface elevation in bridge opening $\quad 500.3 \mathrm{ft}$

Road overtopping? ___ Yes Discharge over road __ $425 \mathrm{ft}^{3} / \mathrm{s}$

Area of flow in bridge opening $\quad 177 \quad \mathrm{ft}^{2}$

Average velocity in bridge opening $10.1 \mathrm{ft} / \mathrm{s}$

Maximum WSPRO tube velocity at bridge 13.3 , s

Water-surface elevation at Approach section with bridge 502.8

Water-surface elevation at Approach section without bridge $\quad 499.5$

Amount of backwater caused by bridge $\quad 3.3$.t

Incipient overtopping discharge $\quad 1,040 \quad \mathrm{ft}^{3} / \mathrm{s}$

Water-surface elevation in bridge opening $496.4 \quad t$

Area of flow in bridge opening $\quad 95 \quad \mathrm{ft}^{2}$

Average velocity in bridge opening $11.0 \quad \mathrm{ft} / \mathrm{s}$

Maximum WSPRO tube velocity at bridge $\quad 15.4 \mathrm{ft} / \mathrm{s}$

Water-surface elevation at Approach section with bridge

Water-surface elevation at Approach section without bridge

499.8

Amount of backwater caused by bridge $\quad 2.2$, $t$ 


\section{Scour Analysis Summary}

\section{Special Conditions or Assumptions Made in Scour Analysis}

Scour depths were computed using the general guidelines described in Hydraulic Engineering Circular 18 (Richardson and Davis, 1995). Scour depths were calculated assuming an infinite depth of erosive material and a homogeneous particle-size distribution. The results of the scour analyses for the 100- and 500-year discharges are presented in tables 1 and 2 and the scour depths are shown graphically in figure 8 .

Contraction scour for the incipient roadway-overtopping discharge was computed by use of the Laursen clear-water contraction scour equation (Richardson and Davis, 1995, p. 32 , equation 20). The 100-year and 500-year discharges resulted in an unsubmerged orifice flow solution. Contraction scour at bridges with orifice flow is best estimated by use of the Chang pressure-flow scour equation (oral communication, J. Sterling Jones, October 4, 1996). Thus, contraction scour for these discharges was computed by use of the Chang pressure-flow scour equation (Richardson and Davis, 1995, p. 145-146). The streambed armoring depths computed suggest that armoring will not limit the depth of contraction scour.

For comparison, estimates of contraction scour also were computed for the discharges resulting in orifice flow by use of the Laursen clear-water contraction scour equation (Richardson and Davis, 1995, p. 32, equation 20) and the Umbrell pressure-flow equation (Richardson and Davis, 1995, p. 144). Results of these computations are presented in appendix F. Furthermore, for those discharges resulting in unsubmerged orifice flow, contraction scour was computed by substituting estimates for the depth of flow at the downstream bridge face in the contraction scour equations. Results with respect to these substitutions also are provided in appendix F.

Abutment scour was computed by use of the Froehlich equation (Richardson and Davis, 1995, p. 48, equation 28). Variables for the Froehlich equation include the Froude number of the flow approaching the embankments, the length of the embankment blocking flow, and the depth of flow approaching the embankment less any roadway overtopping. 


\section{Scour Results}

100-yr discharge 500-yr discharge

(Scour depths in feet)

Main channel

Live-bed scour

Clear-water scour

Depth to armoring

Left overbank

Right overbank

Local scour:

Abutment scour

Left abutment

Right abutment

Pier scour

Pier 1

Pier 2

Pier 3

\section{Abutments:}

Left abutment

Right abutment

Piers:

Pier 1

Pier 2

Incipient overtopping discharge
5.2

9.6-

\section{$12.88 .4^{-}$}
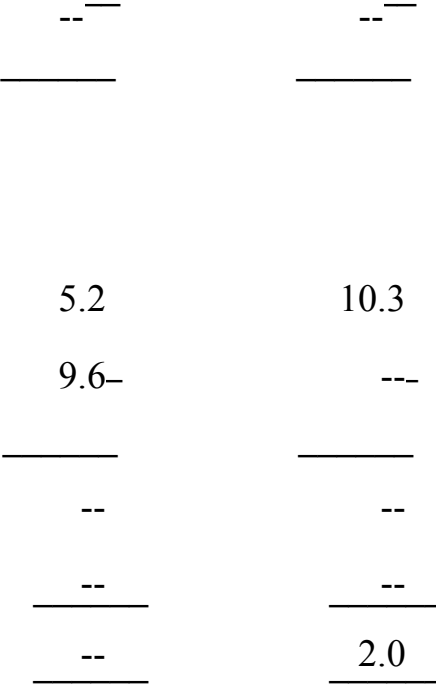

$$
10.3
$$
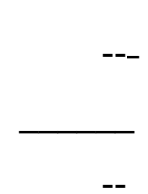

10.8

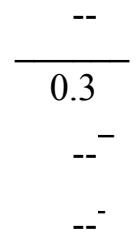

$7.38 .7^{-}$

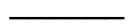

\section{Riprap Sizing}

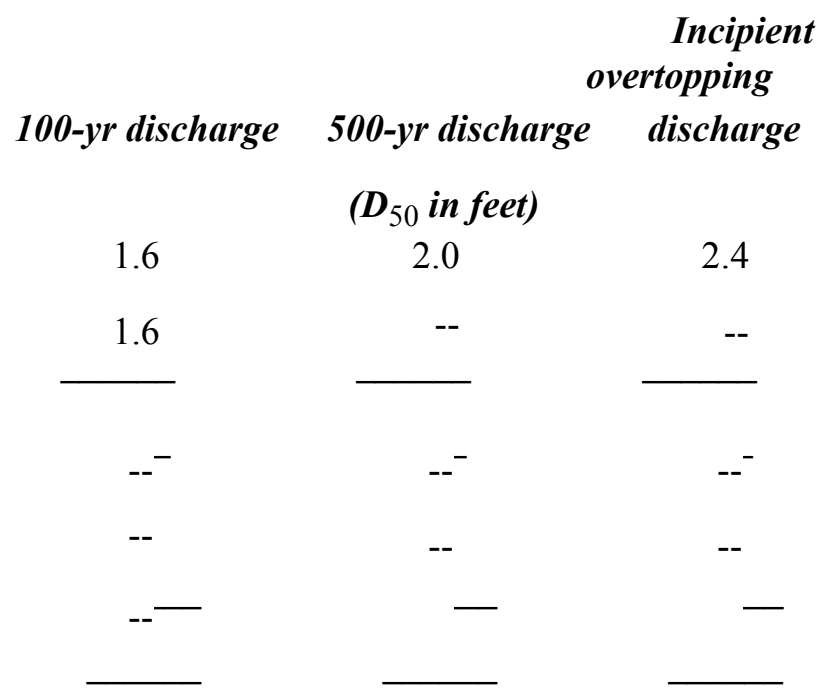




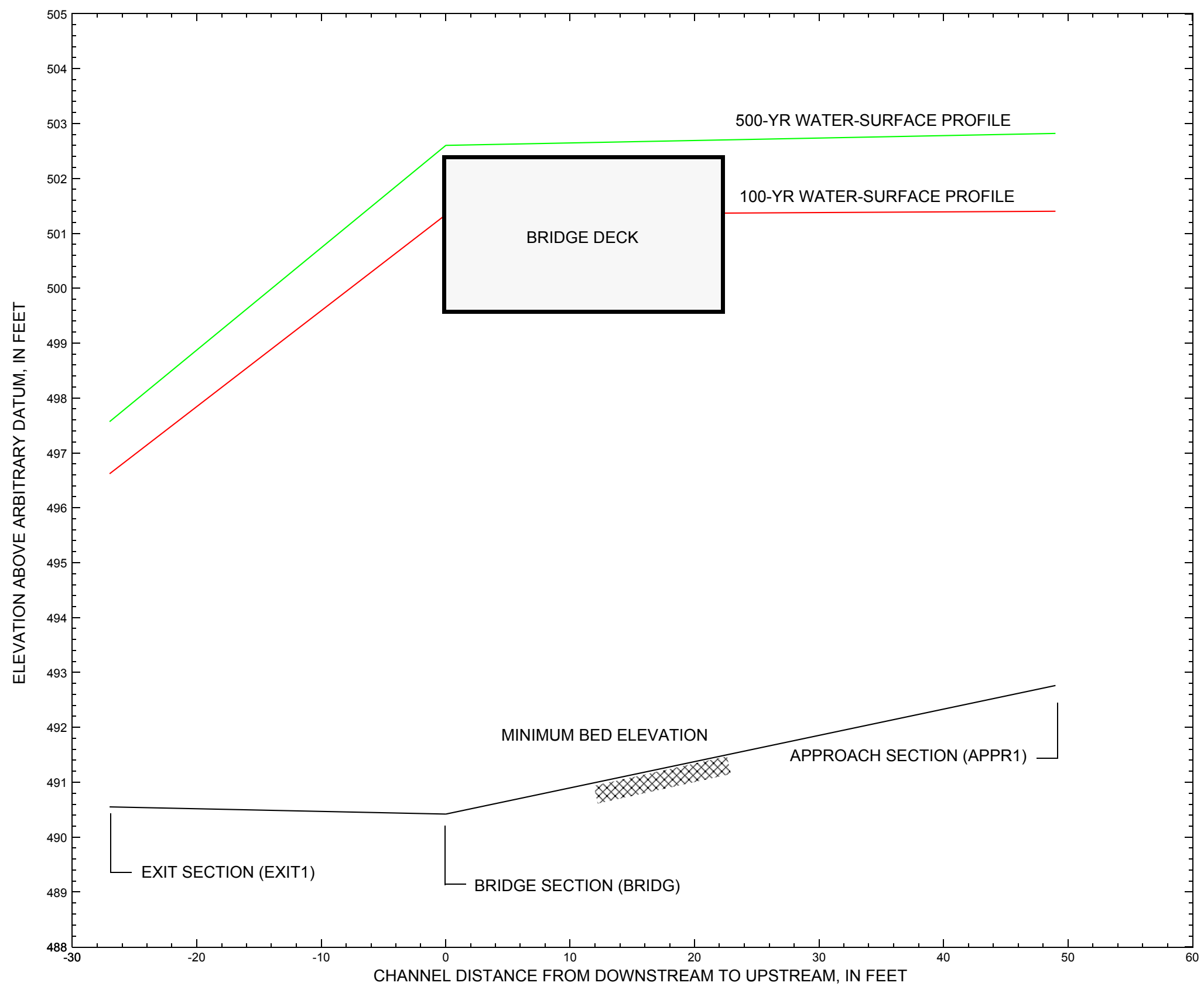

Figure 7. Water-surface profiles for the 100- and 500-yr discharges at structure CHESTH00100052 on Town Highway 10, crossing the South Branch Williams River, Chester, Vermont. 


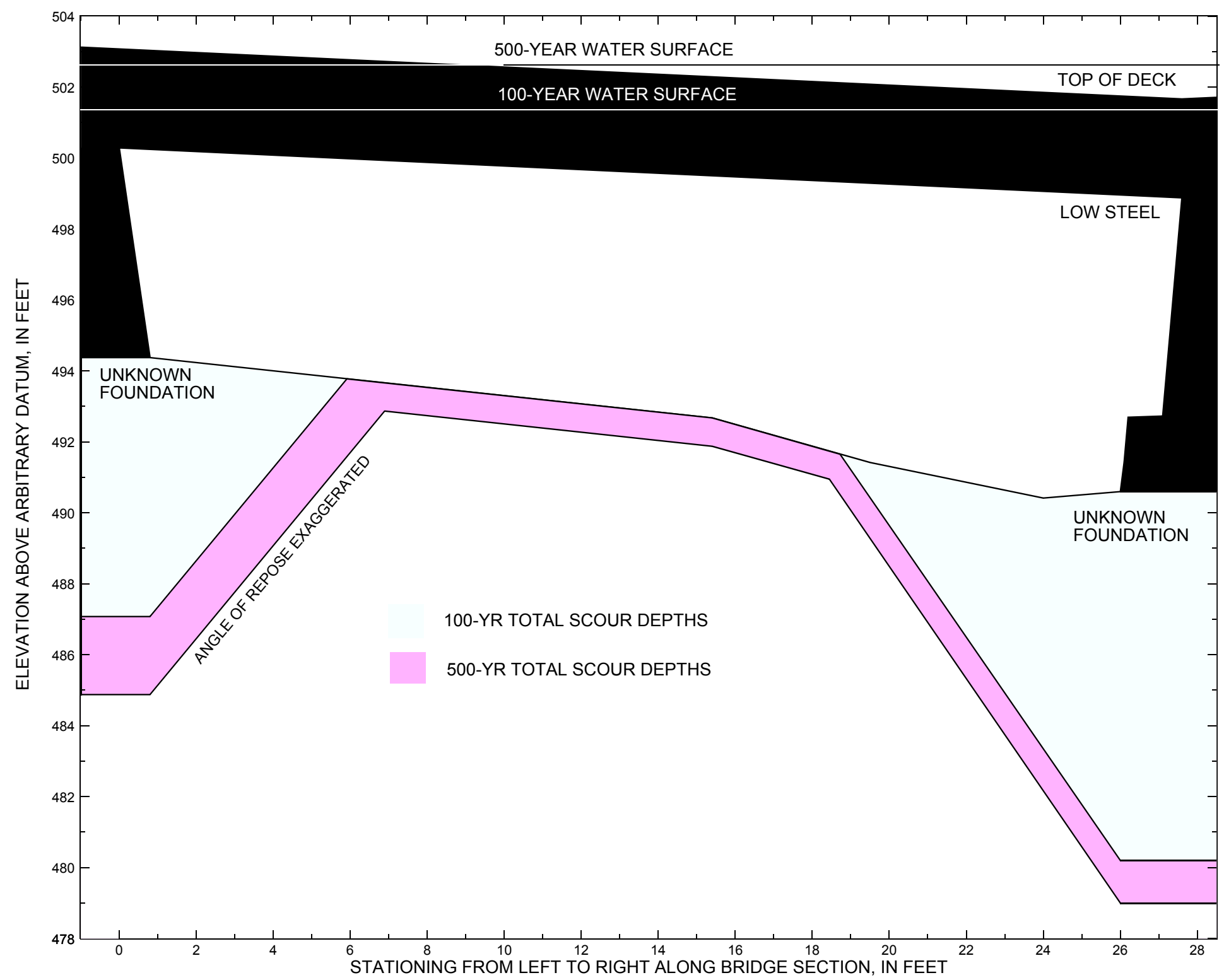

Figure 8. Scour elevations for the 100- and 500-yr discharges at structure CHESTH00100052 on Town Highway 10, crossing the South Branch Williams River, Chester, Vermont. 
Table 1. Remaining footing/pile depth at abutments for the 100-yr discharge at structure CHESTH00100052 on Town Highway 10, crossing the South Branch Williams River, Chester, Vermont.

[VTAOT, Vermont Agency of Transportation; --, no data]

\begin{tabular}{|c|c|c|c|c|c|c|c|c|c|c|c|}
\hline Description & Station $^{1}$ & $\begin{array}{l}\text { VTAOT } \\
\text { minimum } \\
\text { low-chord } \\
\text { elevation } \\
\text { (feet) }\end{array}$ & $\begin{array}{c}\text { Surveyed } \\
\text { minimum } \\
\text { low-chord } \\
\text { elevation }{ }^{2} \\
\text { (feet) }\end{array}$ & $\begin{array}{l}\text { Bottom of } \\
\text { footing } \\
\text { elevation } \\
\text { (feet) }\end{array}$ & $\begin{array}{c}\text { Channel } \\
\text { elevation at } \\
\text { abutment/ } \\
\text { pier }^{2} \\
\text { (feet) }\end{array}$ & $\begin{array}{l}\text { Contraction } \\
\text { scour depth } \\
\text { (feet) }\end{array}$ & $\begin{array}{l}\text { Abutment } \\
\text { scour } \\
\text { depth } \\
\text { (feet) }\end{array}$ & $\begin{array}{l}\text { Pier } \\
\text { scour } \\
\text { depth } \\
\text { (feet) }\end{array}$ & $\begin{array}{l}\text { Depth of } \\
\text { total scour } \\
\text { (feet) }\end{array}$ & $\begin{array}{c}\text { Elevation of } \\
\text { scour }^{2} \\
\text { (feet) }\end{array}$ & $\begin{array}{c}\text { Remaining } \\
\text { footing/pile } \\
\text { depth } \\
\text { (feet) }\end{array}$ \\
\hline \multicolumn{12}{|c|}{100 -yr. discharge is 1,550 cubic-feet per second } \\
\hline Left abutment & 0.0 & -- & 500.3 & -- & 494.4 & 0.0 & 7.3 & -- & 7.3 & 487.1 & -- \\
\hline Right abutment & 27.6 & -- & 498.9 & -- & 490.6 & 0.0 & 10.3 & -- & 10.3 & 480.3 & -- \\
\hline
\end{tabular}

1.Measured along the face of the most constricting side of the bridge.

2.Arbitrary datum for this study.

Table 2. Remaining footing/pile depth at abutments for the 500-yr discharge at structure CHESTH00100052 on Town Highway 10, crossing the South Branch Williams River, Chester, Vermont.

[VTAOT, Vermont Agency of Transportation; --, no data]

\begin{tabular}{|c|c|c|c|c|c|c|c|c|c|c|c|}
\hline Description & Station $^{1}$ & $\begin{array}{l}\text { VTAOT } \\
\text { minimum } \\
\text { low-chord } \\
\text { elevation } \\
\text { (feet) }\end{array}$ & $\begin{array}{c}\text { Surveyed } \\
\text { minimum } \\
\text { low-chord } \\
\text { elevation } \\
\text { (feet) }\end{array}$ & $\begin{array}{l}\text { Bottom of } \\
\text { footing } \\
\text { elevation } \\
\text { (feet) }\end{array}$ & $\begin{array}{c}\text { Channel } \\
\text { elevation at } \\
\text { abutment/ } \\
\text { pier }^{2} \\
\text { (feet) }\end{array}$ & $\begin{array}{l}\text { Contraction } \\
\text { scour depth } \\
\text { (feet) }\end{array}$ & $\begin{array}{l}\text { Abutment } \\
\text { scour } \\
\text { depth } \\
\text { (feet) }\end{array}$ & $\begin{array}{l}\text { Pier } \\
\text { scour } \\
\text { depth } \\
\text { (feet) }\end{array}$ & $\begin{array}{l}\text { Depth of } \\
\text { total scour } \\
\text { (feet) }\end{array}$ & $\begin{array}{c}\text { Elevation of } \\
\text { scour }^{2} \\
\text { (feet) }\end{array}$ & $\begin{array}{c}\text { Remaining } \\
\text { footing/pile } \\
\text { depth } \\
\text { (feet) }\end{array}$ \\
\hline \multicolumn{12}{|c|}{500 -yr. discharge is 2,200 cubic-feet per second } \\
\hline Left abutment & 0.0 & -- & 500.3 & -- & 494.4 & 0.8 & 8.7 & -- & 9.5 & 484.9 & -- \\
\hline Right abutment & 27.6 & -- & 498.9 & -- & 490.6 & 0.8 & 10.8 & -- & 11.6 & 479.0 & -- \\
\hline
\end{tabular}

1.Measured along the face of the most constricting side of the bridge.

2.Arbitrary datum for this study. 


\section{SELECTED REFERENCES}

Arcement, G.J., Jr., and Schneider, V.R., 1989, Guide for selecting Manning's roughness coefficients for natural channels and flood plains: U.S. Geological Survey Water-Supply Paper 2339, 38 p.

Barnes, H.H., Jr., 1967, Roughness characteristics of natural channels: U.S. Geological Survey Water-Supply Paper 1849,213 p.

Benson, M. A., 1962, Factors Influencing the Occurrence of Floods in a Humid Region of Diverse Terrain: U.S. Geological Survey WaterSupply Paper 1580-B, 64 p.

Brown, S.A. and Clyde, E.S., 1989, Design of riprap revetment: Federal Highway Administration Hydraulic Engineering Circular No. 11, Publication FHWA-IP-89-016, 156 p.

Federal Highway Administration, 1983, Runoff estimates for small watersheds and development of sound design: Federal Highway Administration Report FHWA-RD-77-158.

Federal Highway Administration, 1993, Stream Stability and Scour at Highway Bridges: Participant Workbook: Federal Highway Administration Report FHWA-HI-91-011.

Federal Emergency Management Agency, 1982, Flood Insurance Study, Town of Chester, Windsor County, Vermont: Washington, D.C., February 1982.

Froehlich, D.C., 1989, Local scour at bridge abutments in Ports, M.A., ed., Hydraulic Engineering--Proceedings of the 1989 National Conference on Hydraulic Engineering: New York, American Society of Civil Engineers, p. 13-18.

Hayes, D.C.,1993, Site selection and collection of bridge-scour data in Delaware, Maryland, and Virginia: U.S. Geological Survey WaterResources Investigation Report 93-4017, 23 p.

Interagency Advisory Committee on Water Data, 1982, Guidelines for determining flood flow frequency: U.S. Geological Survey, Bulletin 17B of the Hydrology Subcommittee, 190 p.

Johnson, C.G. and Tasker, G.D.,1974, Progress report on flood magnitude and frequency of Vermont streams: U.S. Geological Survey OpenFile Report 74-130, 37 p.

Lagasse, P.F., Schall, J.D., Johnson, F., Richardson, E.V., Chang, F., 1995, Stream Stability at Highway Structures: Federal Highway Administration Hydraulic Engineering Circular No. 20, Publication FHWA-IP-90-014, 144 p.

Laursen, E.M., 1960, Scour at bridge crossings: Journal of the Hydraulics Division, American Society of Civil Engineers, v. 86, no. HY2, p. 39-53.

Potter, W. D., 1957a, Peak rates of runoff in the Adirondack, White Mountains, and Maine woods area, Bureau of Public Roads

Potter, W. D., 1957b, Peak rates of runoff in the New England Hill and Lowland area, Bureau of Public Roads

Richardson, E.V. and Davis, S.R., 1995, Evaluating scour at bridges: Federal Highway Administration Hydraulic Engineering Circular No. 18, Publication FHWA-IP-90-017, 204 p.

Richardson, E.V., Simons, D.B., and Julien, P.Y., 1990, Highways in the river environment: Federal Highway Administration Publication FHWA-HI-90-016.

Ritter, D.F., 1984, Process Geomorphology: W.C. Brown Co., Debuque, Iowa, 603 p.

Shearman, J.O., 1990, User's manual for WSPRO--a computer model for water surface profile computations: Federal Highway Administration Publication FHWA-IP-89-027, 187 p.

Shearman, J.O., Kirby, W.H., Schneider, V.R., and Flippo, H.N., 1986, Bridge waterways analysis model; research report: Federal Highway Administration Publication FHWA-RD-86-108, 112 p.

Talbot, A.N., 1887, The determination of water-way for bridges and culverts.

U.S. Geological Survey, 1984, Saxtons River, Vermont 7.5 X 15 Minute Series quadrangle map: U.S. Geological Survey Topographic Maps, Scale 1:25,000. 


\section{APPENDIX A:}

WSPRO INPUT FILE 


\section{WSPRO INPUT FILE}

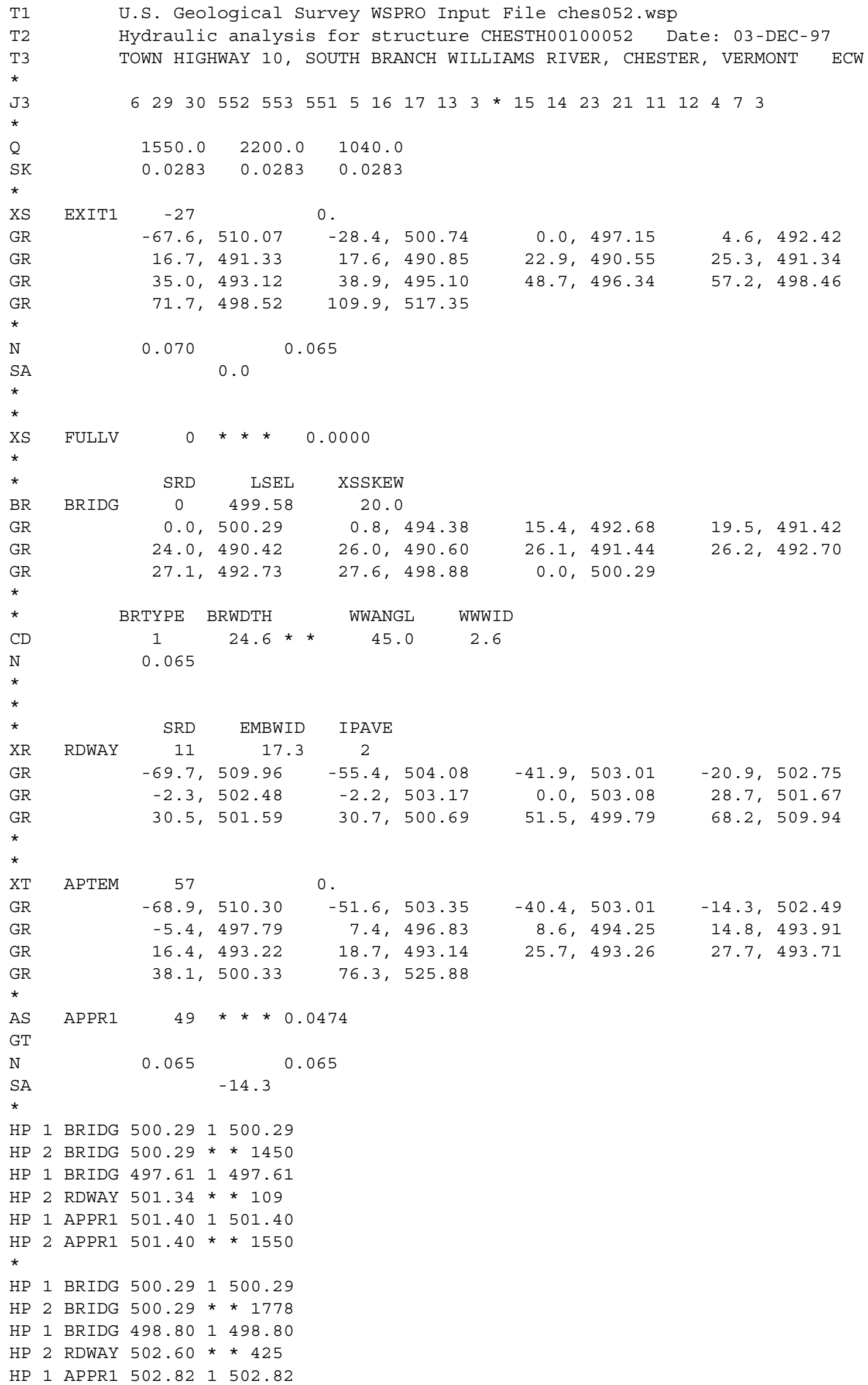




\section{APPENDIX B: \\ WSPRO OUTPUT FILE}




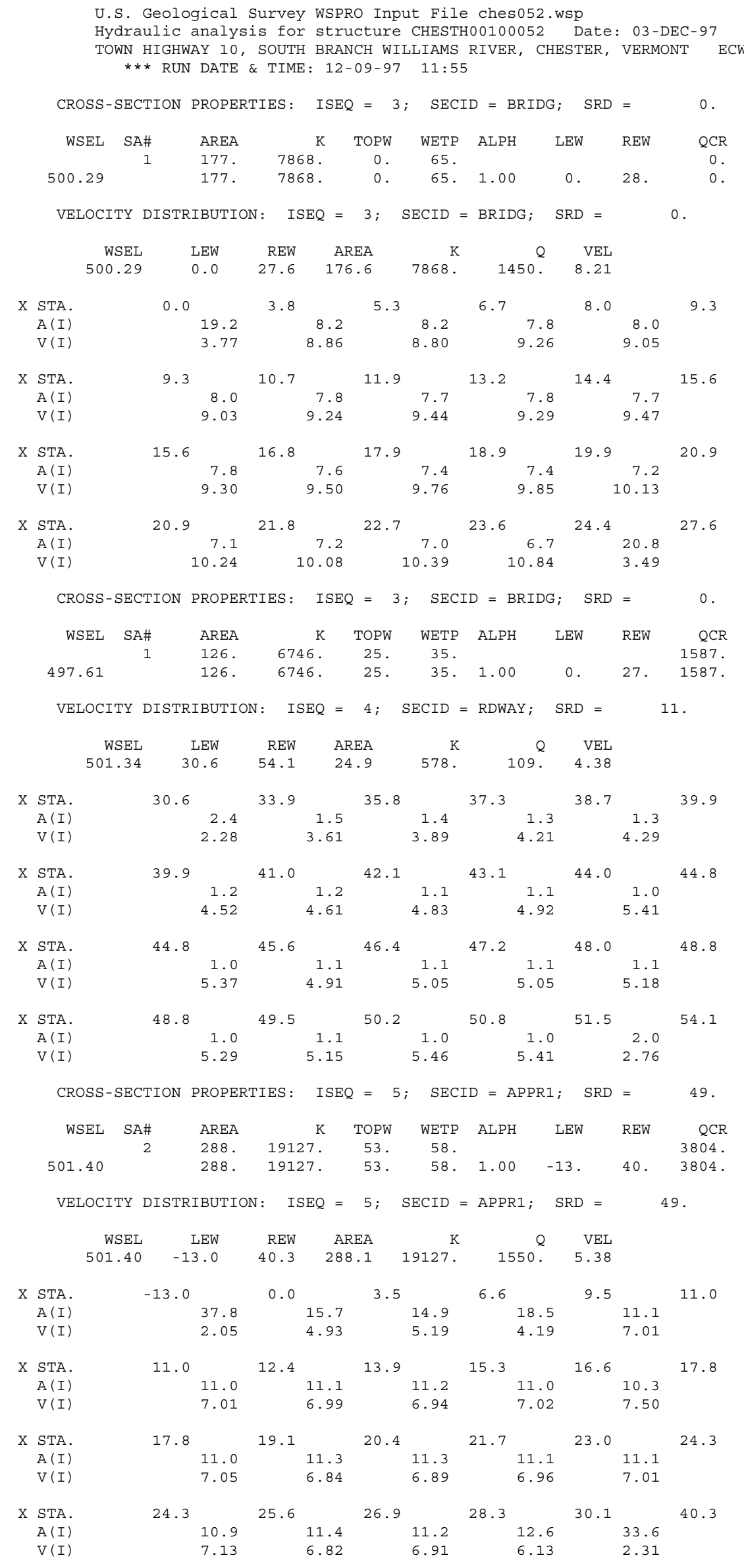




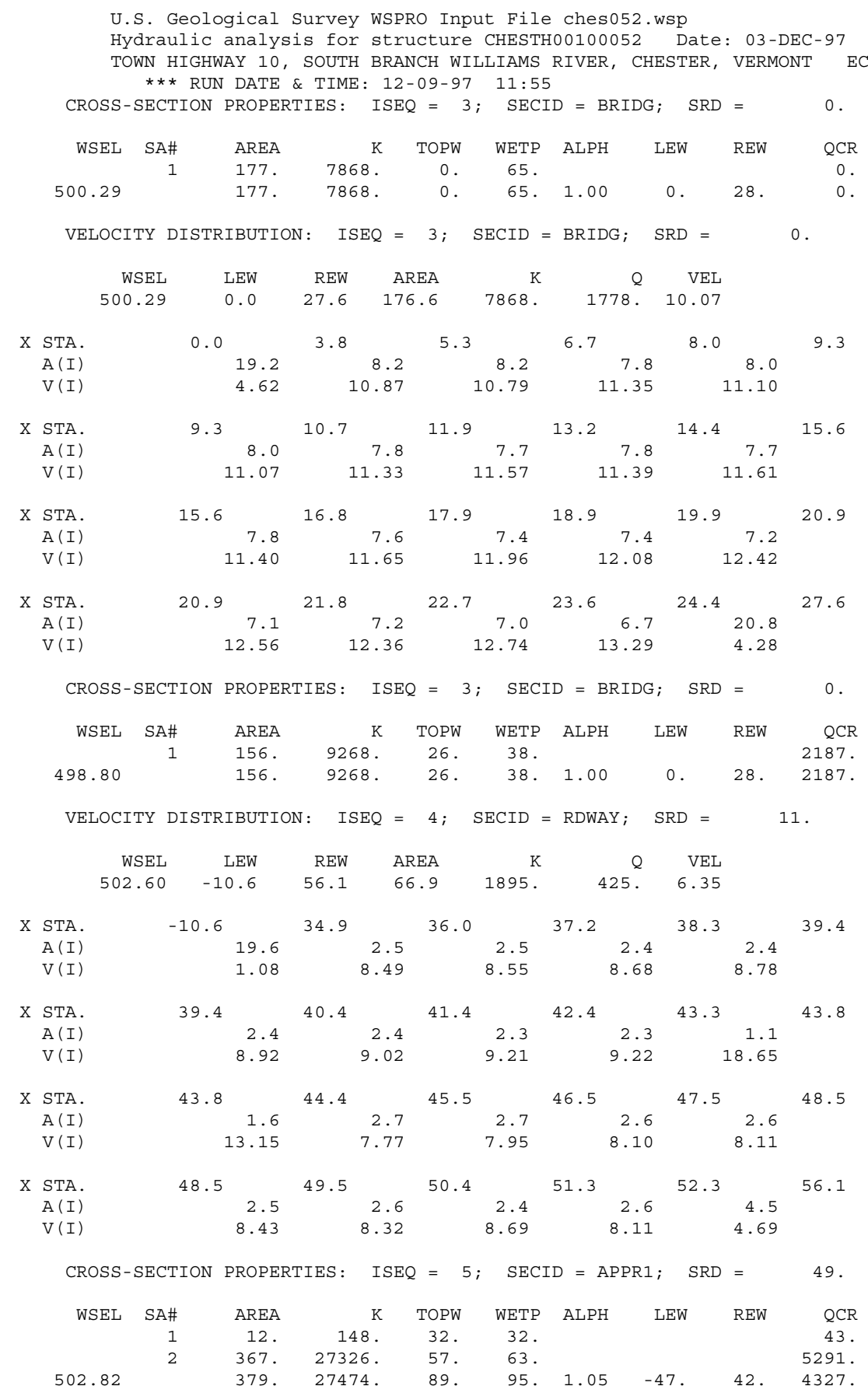

VELOCITY DISTRIBUTION: ISEQ $=5 ;$ SECID $=$ APPRI $;$ SRD $=49$.

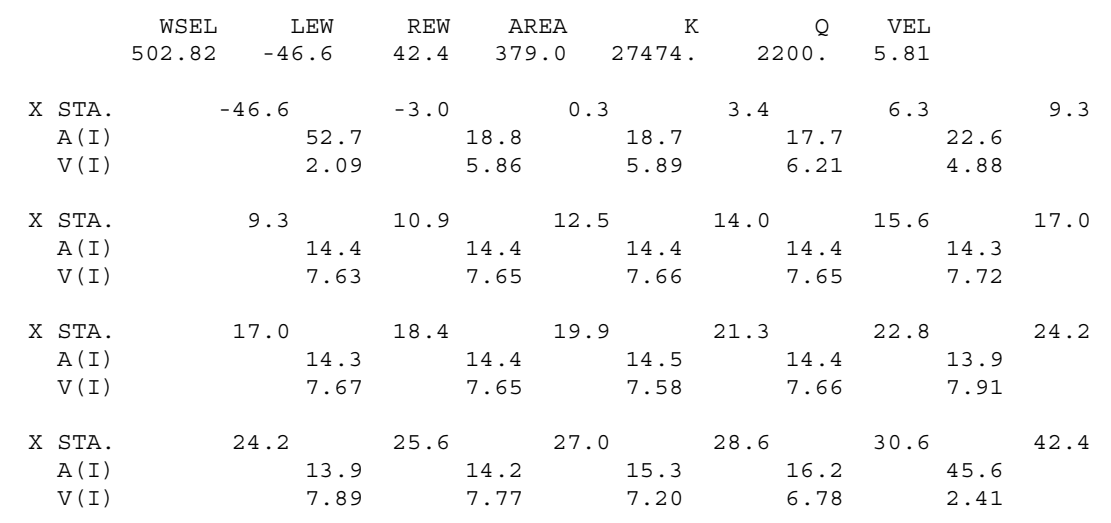


WSPRO OUTPUT FILE (continued)

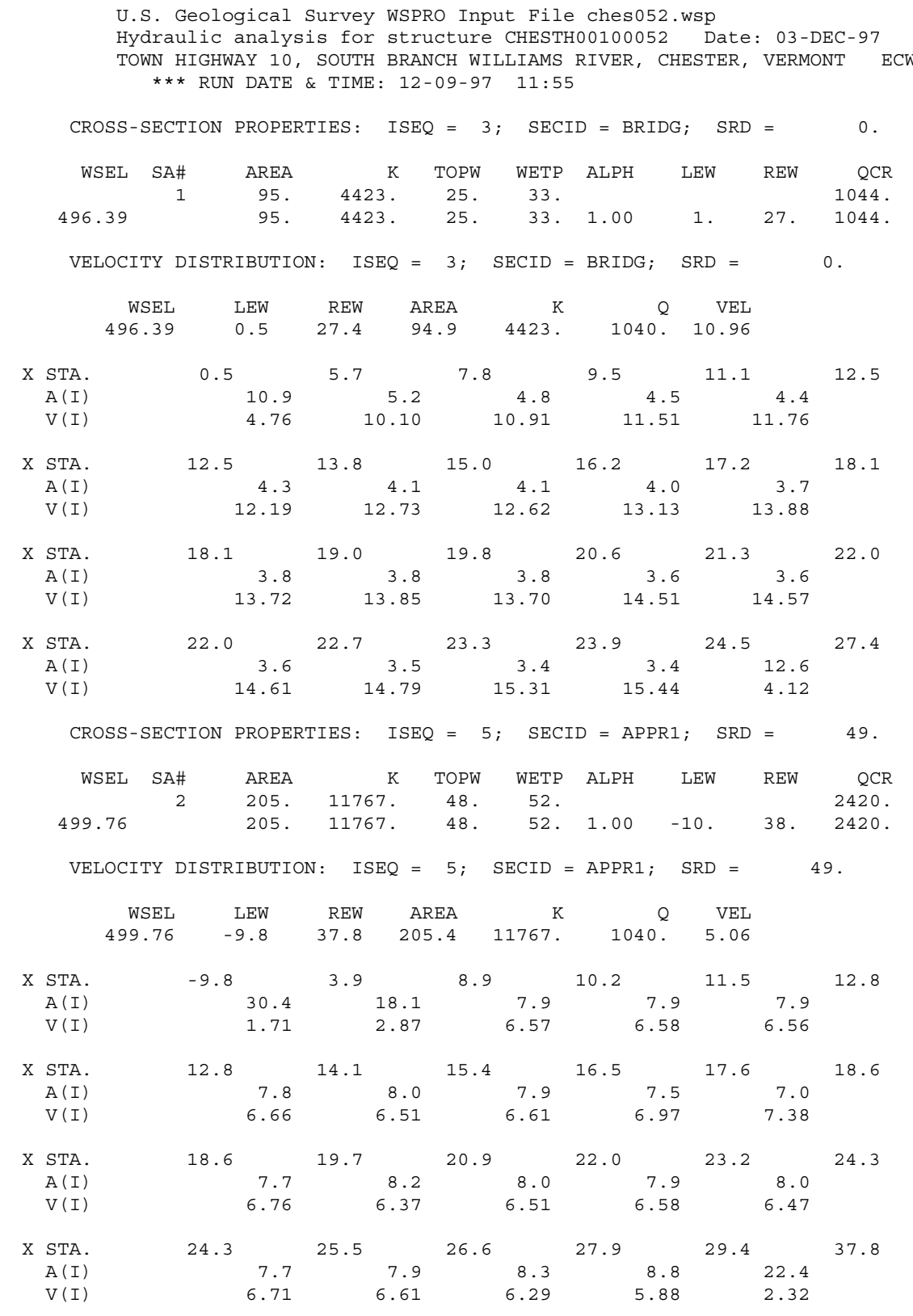


WSPRO OUTPUT FILE (continued)

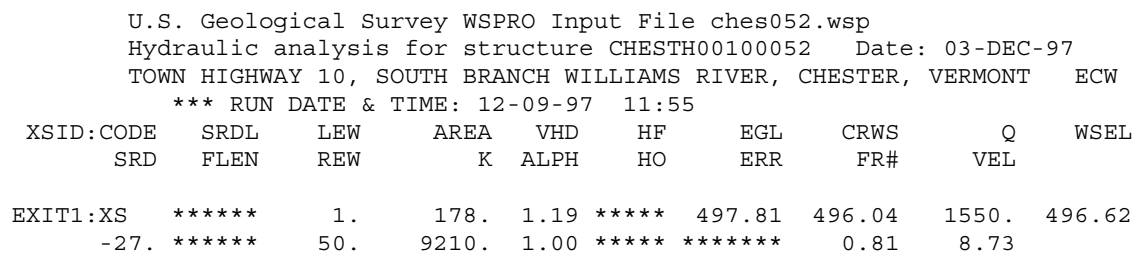

$===135$ CONVEYANCE RATIO OUTSIDE OF RECOMMENDED LIMITS.

"FULLV" KRATIO $=1.44$

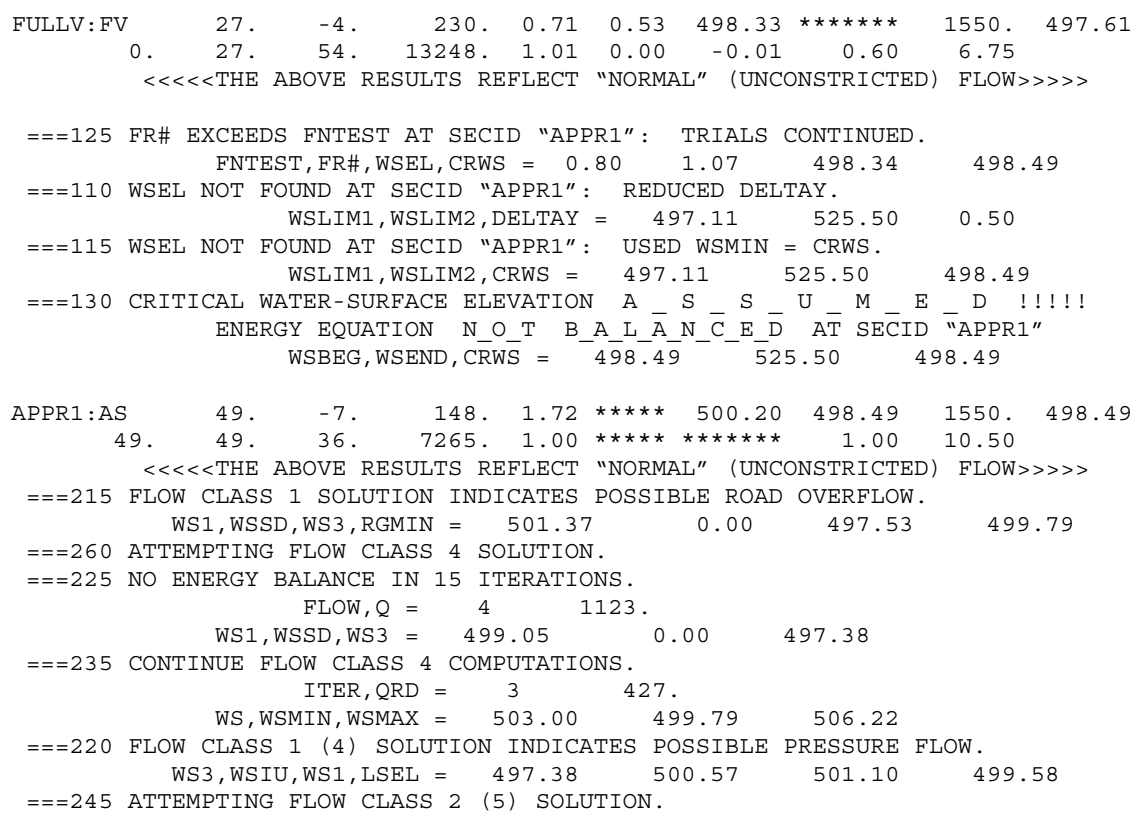


WSPRO OUTPUT FILE (continued)

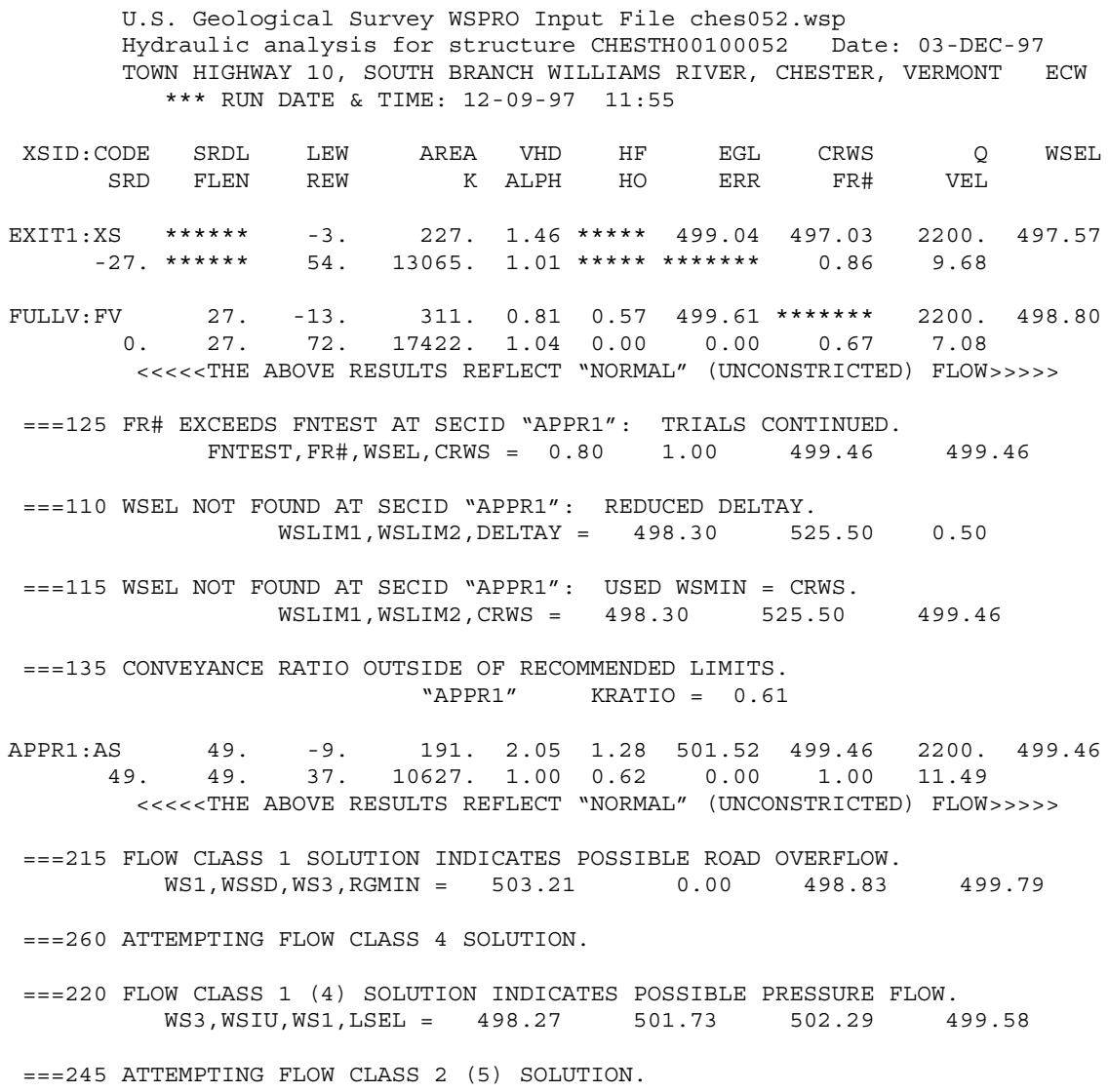


WSPRO OUTPUT FILE (continued)

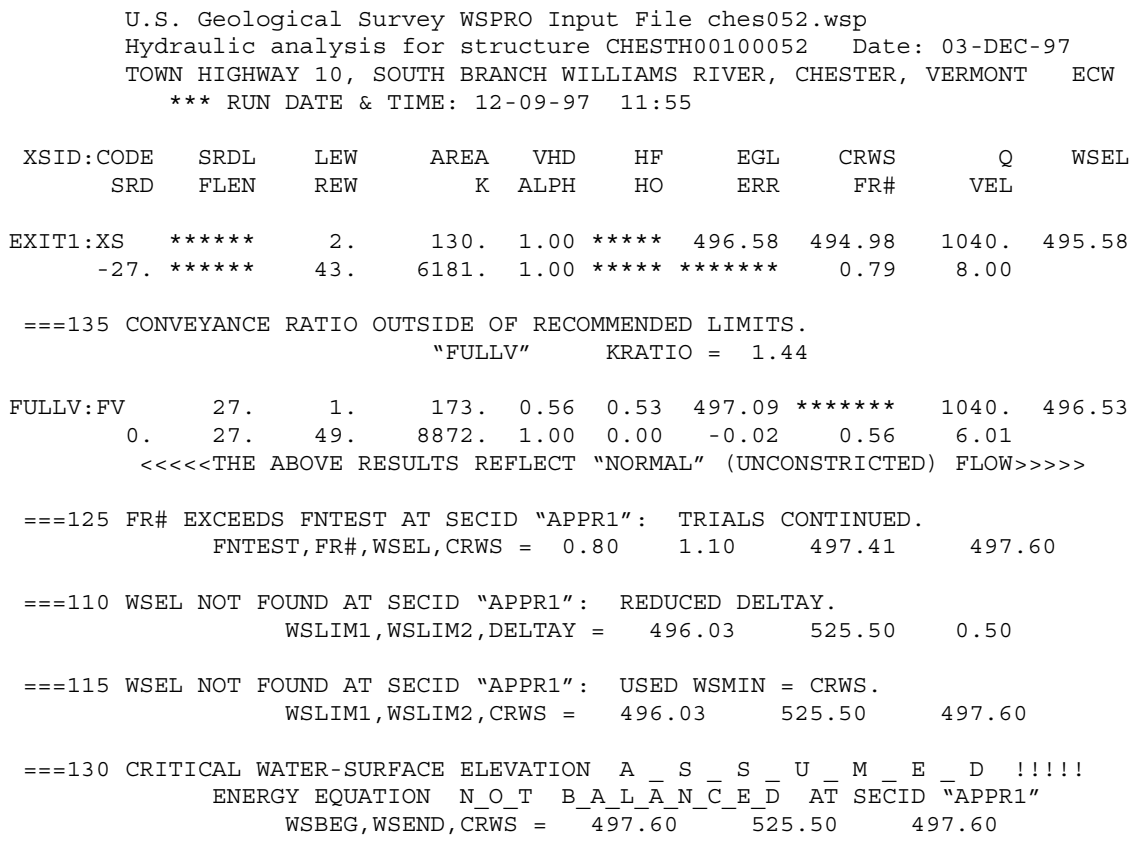

SECOND USER DEFINED TABLE.

$\begin{array}{lrrrrrrrrr}\text { XSID : CODE } & \text { CRWS } & \text { FR\# } & \text { YMIN } & \text { YMAX } & \text { HF } & \text { HO } & \text { VHD } & \text { EGL } & \text { WSEL } \\ \text { EXIT1:XS } & 494.98 & 0.79 & 490.55 & 517.35 * * * * * * * * * * & 1.00 & 496.58 & 495.58 \\ \text { FULLV:FV } & * * * * * * * & 0.56 & 490.55 & 517.35 & 0.53 & 0.00 & 0.56 & 497.09 & 496.53 \\ \text { BRIDG:BR } & 496.39 & 1.00 & 490.42 & 500.29 * * * * * * * * * * & 1.87 & 498.26 & 496.39 \\ \text { RDWAY:RG } & * * * * * * * * * * * * * * * & 499.79 & 509.96 * * * * * * * * * * * * * * * * * * * * * * * * * * * * * \\ \text { APPR1:AS } & 497.60 & 0.43 & 492.76 & 525.50 & 0.54 & 1.36 & 0.40 & 500.16 & 499.76\end{array}$

NORMAL END OF WSPRO EXECUTION. 
APPENDIX C:

BED-MATERIAL PARTICLE-SIZE DISTRIBUTION 


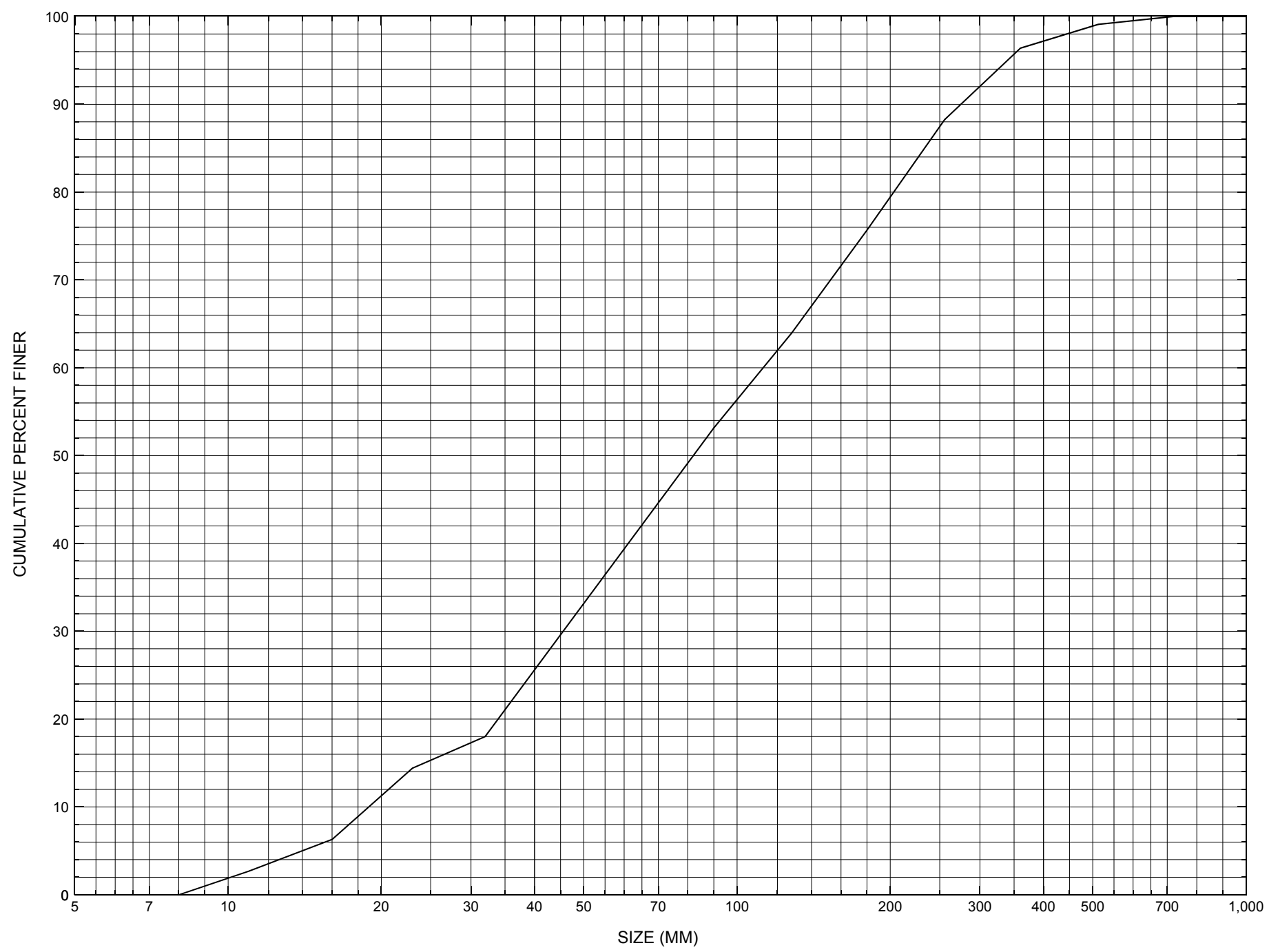

Appendix C. Bed material particle-size distribution for a pebble count in the channel approach of structure CHESTH00100052, in Chester, Vermont. 


\section{APPENDIX D: \\ HISTORICAL DATA FORM}




\section{Structure Number CHESTH00100052}

\section{General Location Descriptive}

Data collected by (First Initial, Full last name) $\underline{\text { L }}$. MEDALIE

Date $(M M / D D / Y Y) \_\mathbf{0 3} / \underline{31} / \underline{95}$

Highway District Number $(I-2 ; n n) \underline{\mathbf{0 2}}$

Town (FIPS place code; I - 4; nnnnn) 13675

Waterway (I - 6) SO BR OF WILLIAMS R

Route Number $\underline{\text { TH010 }}$

Topographic Map Saxtons River

Latitude (I - 16; nnnn.n) $\mathbf{4 3 1 3 8}$
County (FIPS county code; I - 3; nnn)

Mile marker (I - 11; nnn.nnn) $\mathbf{0 0 0 0 0 0}$

Road Name (I - 7): -

Vicinity (I - 9) 0.25 MI TO JCT W C3 TH63

Hydrologic Unit Code: $\mathbf{0 1 0 8 0 1 0 7}$

Longitude (i - 17; nnnnn.n) $\mathbf{7 2 4 0 1}$

\section{Select Federal Inventory Codes}

FHWA Structure Number $(I$ - 8) $\mathbf{1 0 1 4 0 7 0 0 5 2 1 4 0 7}$

Maintenance responsibility $(I-21 ; n n) \quad \mathbf{0 3}$

Year built (I - 27; YYYY) 1939

Average daily traffic, ADT (I - 29; nnnnnn) 000060

Year of ADT (I - 30; YY) $\mathbf{9 1}$

Opening skew to Roadway $(I-34 ; n n) \quad \mathbf{2 0}$

Operational status $(I-41 ; X) \quad \mathbf{A}$

Structure type (I - 43; nnn) $\mathbf{3 0 2}$

Approach span structure type $(I-44 ; n n n) \quad \mathbf{0 0 0}$

Number of spans (I - 45; nnn) $\mathbf{0 0 1}$

Number of approach spans (I - 46; nnnn) $\mathbf{0 0 0 0}$

Comments:

The structural inspection report states the structure is a steel stringer type bridge with a concrete deck. The right abutment and wingwalls have some horizontal cracks with heavy leakage reported at each end. A few minor spalls are noted in these cracked areas. The left abutment has a few minor cracks with faint stains. The footings are exposed along both abutment walls. The downstream half of the right abutment is undermined. A stick can penetrate below the footing roughly two feet. The upstream end of left abutment has some minor erosion of the concrete. There is some localized scour at the downstream end of the right abutment. The river makes a moderate to sharp turn through the structure. (Continued, page 33) 


\section{Bridge Hydrologic Data}

Is there hydrologic data available? if No, type ctrl-n $h \quad$ VTAOT Drainage area $\left(m i^{2}\right)$ :

Terrain character: Hilly, forested

Stream character \& type: -

Streambed material: Stone and gravel with some random boulders

Discharge Data (cfs): $\quad Q_{2.33} \underline{\mathbf{4 0 0}}$

$\mathrm{Q}_{50} \mathbf{1 3 0 0}$

$Q_{10} \frac{\mathbf{8 0 0}}{\mathbf{1 5 5 0}}$

$\mathrm{Q}_{25}$

$Q_{500 \_-}$

Record flood date (MM /DD/YY): - $/$ - $/$

Water surface elevation $(f t):-$

Estimated Discharge (cfs):

Velocity at $\mathrm{Q}$ $(\mathrm{ft} / \mathrm{s}):$

Ice conditions (Heavy, Moderate, Light) : -

Debris (Heavy, Moderate, Light):

The stage increases to maximum highwater elevation (Rapidly, Not rapidly):

The stream response is (Flashy, Not flashy):

Describe any significant site conditions upstream or downstream that may influence the stream's stage: -

Watershed storage area (in percent): 1

The watershed storage area is: - _ (1-mainly at the headwaters; 2- uniformly distributed; 3-immediatly upstream oi the site)

Water Surface Elevation Estimates for Existing Structure:

\begin{tabular}{|l|l|l|l|l|l|}
\hline Peak discharge frequency & $Q_{2.33}$ & $Q_{10}$ & $Q_{25}$ & $Q_{50}$ & $Q_{100}$ \\
Water surface elevation (ft) $)$ & - & - & - & - & - \\
Velocity $(\mathrm{ft} / \mathrm{sec})$ & - & - & - & - & - \\
\hline
\end{tabular}

Long term stream bed changes: -

Is the roadway overtopped below the $\mathrm{Q}_{100}$ ? (Yes, No, Unknown): $\mathbf{U} \quad$ Frequency: -

Relief Elevation $(f t)$ :

Discharge over roadway at $Q_{100}\left(f^{3} / \mathrm{sec}\right)$ :

Are there other structures nearby? (Yes, No, Unknown): $\mathbf{Y}$ Upstream distance (miles): 2600' Town: If No or Unknown, type ctrl-n os Highway No. : TH92 Structure No. : 46 Structure Type: I-beam, wood Clear span (ft): 19 Clear Height $(f t): \underline{6}$ Full Waterway $\left(f^{2}\right): 144$ 
Downstream distance (miles): 1600' Town:

Chester

Year Built:

Highway No. : TH63 Structure No. : 49 Structure Type: I-beam, wood

Clear span (ft): $\underline{\mathbf{2 0}}$ Clear Height $(f t):$ 6.5 Full Waterway $\left(f^{2}\right): \mathbf{1 3 0}$

Comments:

The upstream bridge (46) washed out in the 1973 flood. The downstream bridge (49) was rebuilt in 1965. All of the flow is presently on the right abutment side of the channel directly in front of the undermined footing. The banks are fairly well protected with stone fill. Channel scour is severe along the right abutment. The bank upstream from the right abutment is well protected with boulders.

\section{USGS Watershed Data}

Watershed Hydrographic Data

Drainage area $(D A)$ 4.05 $\mathrm{mi}^{2}$ Lake/pond/swamp area 0.05 $\mathrm{mi}^{2}$

Watershed storage (ST) $\%$

Bridge site elevation 1342 $\mathrm{ft}$ Headwater elevation 2303 $\mathrm{ft}$

Main channel length 3.87 $\mathrm{mi}$

$10 \%$ channel length elevation $\mathbf{1 4 9 6}$ $\mathrm{ft} \quad 85 \%$ channel length elevation 1759 $\mathrm{ft}$

Main channel slope (S)

(S) 90.48 $\mathrm{ft} / \mathrm{mi}$

Watershed Precipitation Data

Average site precipitation in Average headwater precipitation in

Maximum 2yr-24hr precipitation event $(124,2)$ in

Average seasonal snowfall (Sn) $\mathrm{ft}$ 


\section{Bridge Plan Data}

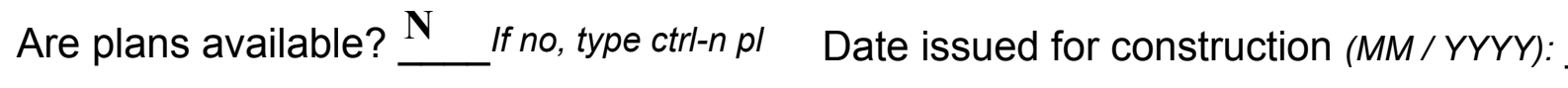

Project Number

Minimum channel bed elevation:

Low superstructure elevation: USLAB DSLAB USRAB DSRAB Benchmark location description:

NO BENCHMARK INFORMATION

Reference Point (MSL, Arbitrary, Other): Datum (NAD27, NAD83, Other):

Foundation Type: 4

If 1 : Footing Thickness

If 2: Pile Type:

If 3: Footing bottom elevation:

Is boring information available? $\mathbf{N}$

Foundation Material Type: $\mathbf{3}$

(1-Spreadfooting; 2-Pile; 3- Gravity; 4-Unknown)

Footing bottom elevation: -

Briefly describe material at foundation bottom elevation or around piles:

NO FOUNDATION MATERIAL INFORMATION

Comments:

NO PLANS. 


\section{Cross-sectional Data}

Is cross-sectional data available? $\mathbf{N}$ If no, type ctrl-n xs

Source (FEMA, VTAOT, Other)? -

Comments:

\section{NO CROSS SECTION INFORMATION}

\begin{tabular}{|l|l|l|l|l|l|l|l|l|l|l|l|}
\hline Station & - & - & - & - & - & - & - & - & - & - & - \\
\hline Feature & - & - & - & - & - & - & - & - & - & - & - \\
\hline $\begin{array}{l}\text { Low chord } \\
\text { elevation }\end{array}$ & - & - & - & - & - & - & - & - & - & - & - \\
\hline $\begin{array}{l}\text { Bed } \\
\text { elevation }\end{array}$ & - & - & - & - & - & - & - & - & - & - & - \\
\hline $\begin{array}{l}\text { Low chord } \\
\text { to bed }\end{array}$ & - & - & - & - & - & - & - & - & - & - & - \\
\hline Station & - & - & - & - & - & - & - & - & - & - & - \\
\hline Feature & - & - & - & - & - & - & - & - & - & - & - \\
\hline $\begin{array}{l}\text { Low chord } \\
\text { elevation }\end{array}$ & - & - & - & - & - & - & - & - & - & - & - \\
\hline $\begin{array}{l}\text { Bed } \\
\text { elevation }\end{array}$ & - & - & - & - & - & - & - & - & - & - & - \\
\hline $\begin{array}{l}\text { Low chord } \\
\text { to bed }\end{array}$ & - & - & - & - & - & - & - & - & - & - & - \\
\hline
\end{tabular}

Source (FEMA, VTAOT, Other)?

Comments: NO CROSS SECTION INFORMATION

\begin{tabular}{|l|l|l|l|l|l|l|l|l|l|l|l|}
\hline Station & - & - & - & - & - & - & - & - & - & - & - \\
\hline Feature & - & - & - & - & - & - & - & - & - & - & - \\
\hline $\begin{array}{l}\text { Low chord } \\
\text { elevation }\end{array}$ & - & - & - & - & - & - & - & - & - & - & - \\
\hline $\begin{array}{l}\text { Bed } \\
\text { elevation }\end{array}$ & - & - & - & - & - & - & - & - & - & - & - \\
\hline $\begin{array}{l}\text { Low chord } \\
\text { to bed }\end{array}$ & - & - & - & - & - & - & - & - & - & - & - \\
\hline Station & - & - & - & - & - & - & - & - & - & - & - \\
\hline Feature & - & - & - & - & - & - & - & - & - & - & - \\
\hline $\begin{array}{l}\text { Low chord } \\
\text { elevation }\end{array}$ & - & - & - & - & - & - & - & - & - & - & - \\
\hline $\begin{array}{l}\text { Bed } \\
\text { elevation }\end{array}$ & - & - & - & - & - & - & - & - & - & - & - \\
\hline $\begin{array}{l}\text { Low chord } \\
\text { to bed }\end{array}$ & - & - & - & - & - & - & - & - & - & - & - \\
\hline
\end{tabular}


APPENDIX E:

LEVEL I DATA FORM 
U. S. Geological Survey

Bridge Field Data Collection and Processing Form

Qa/Qc Check by: $\mathbf{R B}$

Date: $\underline{\mathbf{1 / 2 4 / 9 7}}$

\section{Structure Number CHESTH00100052}

Computerized by: $\underline{\mathbf{R B}}$ Date: $\underline{4} / \mathbf{2 4 / 9 7}$

Reviewd by: $\quad$ EW Date: $\underline{12 / 16 / 97}$

\section{A. General Location Descriptive}

1. Data collected by (First Initial, Full last name) M. IVANOFF

Date $(M M / D D / Y Y)$

08

$21 / 1996$

2. Highway District Number $\mathbf{0 2}$

County 027 Windsor

Waterway (I - 6) South Branch Williams River

Route Number TH 10

3. Descriptive comments:

Located 0.25 miles to junction with TH 63.
Mile marker $\mathbf{0 0 0 0}$

Town 13675 Chester

Road Name -

Hydrologic Unit Code: $\mathbf{0 1 0 8 0 1 0 7}$

\section{B. Bridge Deck Observations}
4. Surface cover... LBUS 6
RBUS 6
LBDS 6
RBDS 6
Overall 6

(2b us,ds,lb,rb: 1- Urban; 2- Suburban; 3- Row crops; 4- Pasture; 5- Shru $b$ - and brushland; 6- Forest; 7- Wetland)
5. Ambient water surface... US $\underline{2}$
UB 2
DS $\underline{2}$
(1- pool; 2- riffle)

6. Bridge structure type 1 (1- single span; 2- multiple span; 3- single arch; 4- multiple arch; 5-cylindrical culvert; 6- box culvert; or 7-other)
7. Bridge length $\mathbf{3 2}$ (feet)
Span length 29
(feet)
Bridge width 17.3 (feet)

\section{Road approach to bridge:}
8. LB 0
RB 1
( 0 even, 1- lower, 2- higher)
9. LB_2
RB $\underline{2}$
(1- Paved, 2- Not paved)

10. Embankment slope (run / rise in feet / foot)

US left

US right

\begin{tabular}{|c|c|c|c|}
\hline \multicolumn{2}{|c|}{ Protection } & \multirow{2}{*}{ 13.Erosion } & \multirow{2}{*}{ 14.Severity } \\
\hline 11.Type & 12.Cond. & & \\
\hline 5 & & 0 & \\
\hline
\end{tabular}

LBUS

RBUS

RBDS

LBDS

\begin{tabular}{l|l}
5 & 1 \\
\hline 0 & - \\
\hline 5 & 1 \\
\hline 5 & 1 \\
\hline
\end{tabular}

\begin{tabular}{l}
0 \\
0 \\
0 \\
\hline
\end{tabular}

Bank protection types: 0- none; 1- < 12 inches,

2- < 36 inches; 3- < 48 inches;

4- < 60 inches; 5- wall / artificial levee

Bank protection conditions: 1- good; 2- slumped;

3- eroded; 4- failed

Erosion: 0 - none; 1- channel erosion; 2

road wash; 3- both; 4- other

Erosion Severity: 0 - none; 1- slight; 2- moderate; 3- severe

\section{Channel approach to bridge (BF):}

15. Angle of approach: 15

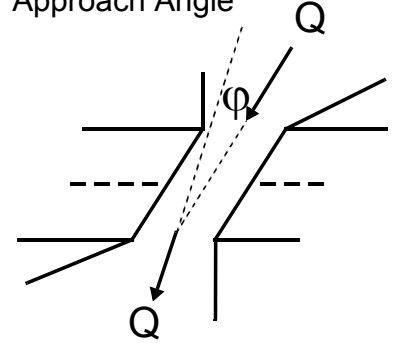

17. Channel impact zone 1 :

Where? RB (LB, RB)

Range? $\underline{30}$ feet US

Channel impact zone 2:

Where? $(L B, R B)$

Range? - $\quad$ feet -

(US, UB, DS) to Impact Severity: 0- none to very slight; 1- Slight; 2-Moderate; 3- Severe feet -

16. Bridge skew: 25 Bridge Skew Angle

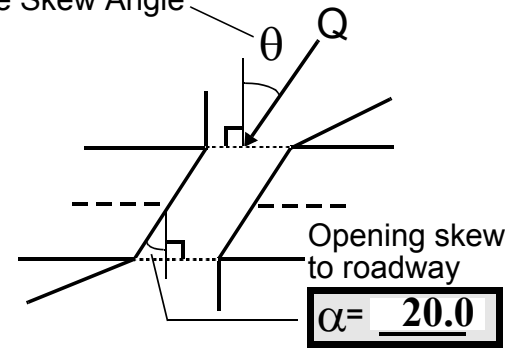

\section{Exist? $\mathbf{Y}(Y$ or $N)$}

Severity 2

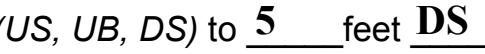

Exist? $\mathbf{N}(Y$ or $N)$

Severity - 
18. Bridge Type: 1a

1a- Vertical abutments with wingwalls

1 b- Vertical abutments without wingwalls

2- Vertical abutments and wingwalls, sloping embankment Wingwalls parallel to abut. face

3- Spill through abutments

4- Sloping embankment, vertical wingwalls and abutments

Wingwall angle less than $90^{\circ}$.

19. Bridge Deck Comments (surface cover variations, measured bridge and span lengths, bridge type variations, approach overflow width, etc.)

7. Values are from the VT AOT files. Measured bridge dimensions are the same.

11. Protection for the road approaches consists of the concrete wingwalls and laid-up stone wall extensions of the wingwalls that also extend above the concrete. The wingwalls are parallel to the road.

18. Only the US right wingwall is not parallel to the road.

\section{Upstream Channel Assessment}

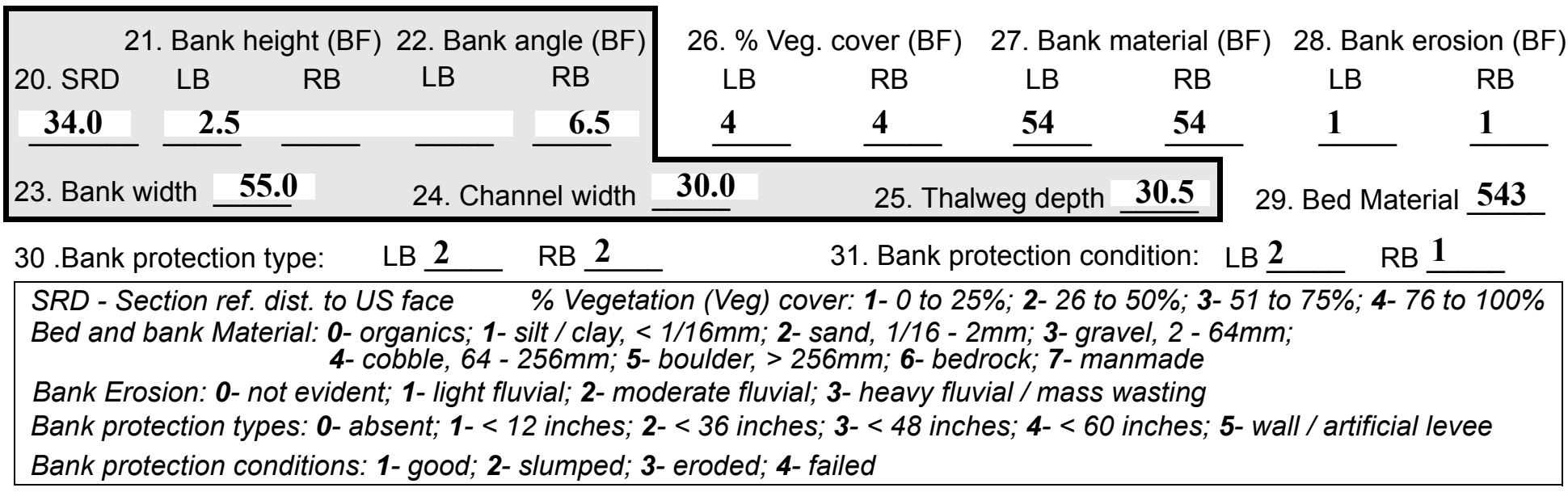

32. Comments (bank material variation, minor inflows, protection extent, etc.):

30. The right bank protection extends $20 \mathrm{ft}$ from the bridge face. The left bank protection extends $4 \mathrm{ft}$ from the US end of the left abutment along the road approach at the base of the US left wingwall. 
36. Point bar extent: $\underline{\mathbf{1 6 0}}$ feet $\underline{\text { US }}$ (US, UB) to $\underline{\mathbf{4 0}}$ feet $\underline{\mathrm{DS}}$ (US, UB, DS) positioned $\underline{\mathbf{0}} \%$ LB to $\underline{\mathbf{8 0}} \%$ RB

37. Material: $4 \mathbf{5 2}$

38. Point or side bar comments (Circle Point or Side; Note additional bars, material variation, status, etc.):

This mid bar of this point bar is at the US bridge face.

39. Is a cut-bank present? $\mathbf{Y}$ ( $Y$ or if $N$ type ctrl-n $c b)$

40. Where? $\underline{\mathbf{L B}}$ (LB or RB)

41. Mid-bank distance: $\mathbf{7 0}$

42. Cut bank extent: 18

43. Bank damage: 1

(1- eroded and/or creep; 2- slip failure; 3- block failure)

44. Cut bank comments (eg. additional cut banks, protection condition, etc.):

The right bank is cut from $100 \mathrm{ft}$ to $180 \mathrm{ft}$ US.

45. Is channel scour present? $\mathbf{N}$ (Y or if $N$ type ctrl-n cs)

47. Scour dimensions: Length Width -

Depth :-

Position -

\%LB to $\% \mathrm{RB}$

48. Scour comments (eg. additional scour areas, local scouring process, etc.):

\section{NO CHANNEL SCOUR}

\section{Are there major confluences? $\mathbf{N}$}

51. Confluence 1: Distance -

Confluence 2: Distance -

\section{NO MAJOR CONFLUENCES}

\section{Under Bridge Channel Assessment}

55. Channel restraint (BF)? LB 2 (1- natural bank; 2- abutment; 3- artificial levee)

\begin{tabular}{|rrr}
\hline \multicolumn{2}{|c|}{ 56. Height (BF) } & \multicolumn{2}{c}{57 Angle } \\
LB & RB & LB \\
$\mathbf{1 9 . 0}$ & & \\
\cline { 1 - 1 } & & $\mathbf{0 . 5}$ \\
\hline
\end{tabular}

58. Bank width (BF) -
52. Enters on -

Enters on ( $L B$ or $R B)$ (LB or $R B)$

53. Type(1- perennial; 2- ephemeral)

Type (1-perennial; 2- ephemeral)

Bed and bank Material: 0- organics; 1- silt / clay, < 1/16mm; 2- sand, 1/16 - 2mm; 3- gravel, 2 - 64mm; 4- cobble, 64 - 256mm; 5- boulder, > 256mm; 6- bedrock; 7- manmade

Bank Erosion: 0- not evident; 1- light fluvial; 2- moderate fluvial; 3- heavy fluvial / mass wasting

64. Comments (bank material variation, minor inflows, protection extent, etc.):

453 
65. Debris and Ice Is there debris accumulation?

$(Y$ or $N)$ 66. Where? $\underline{Y}$

(1- Upstream; 2- At bridge; 3- Both)

67. Debris Potential 1 (1-Low; 2-Moderate; 3- High)

68. Capture Efficiency 2

(1-Low; 2- Moderate; 3- High)

69. Is there evidence of ice build-up? 1 ( 1 or $N)$

Ice Blockage Potential $\mathbf{N}$

(1- Low; 2- Moderate; 3- High)

70. Debris and Ice Comments:

1

There is some debris on the banks with the trees leaning into the channel.

\begin{tabular}{|l|c|c|c|c|c|c|c|c|}
\hline Abutments & $\begin{array}{c}\text { 71. Attack } \\
\angle \text { (BF) }\end{array}$ & $\begin{array}{c}72 \text {. Slope } \angle \\
\text { (Qmax) }\end{array}$ & $\begin{array}{c}\text { 73. Toe } \\
\text { loc. (BF) }\end{array}$ & $\begin{array}{c}\text { 74. Scour } \\
\text { Condition }\end{array}$ & $\begin{array}{c}75 . \text { Scour } \\
\text { depth }\end{array}$ & $\begin{array}{c}\text { 76. Exposure } \\
\text { depth }\end{array}$ & 77. Material & 78. Length \\
\hline LABUT & & $\mathbf{0}$ & $\mathbf{8 5}$ & $\mathbf{2}$ & $\mathbf{2}$ & $\mathbf{0}$ & $\mathbf{1 . 5}$ & $\mathbf{9 0 . 0}$ \\
\hline RABUT & $\mathbf{1}$ & $\mathbf{1 5}$ & $\mathbf{8 5}$ & & & $\mathbf{2}$ & $\mathbf{3}$ & $\mathbf{2 6 . 0}$ \\
\hline
\end{tabular}

Pushed: $L B$ or RB

Toe Location (Loc.): 0- even, 1- set back, 2- protrudes

Scour cond.: 0- not evident; 1- evident (comment); 2- footing exposed; 3-undermined footing; 4- piling exposed; 5- settled; 6- failed

Materials: 1- Concrete; 2- Stone masonry or drywall; 3- steel or metal; 4- wood

79. Abutment comments (eg. undermined penetration, unusual scour processes, debris, etc.):

0.2

2.0

1

The right abutment footing is undermined the entire length. The footing is only exposed $1.5 \mathrm{ft}$ at the US end.

80. Wingwalls:

Exist? Material? Scour Scour Exposure $\begin{aligned} & 81 . \\ & \text { Angle? Length? }\end{aligned}$ Condition? depth? depth?

USLWW:

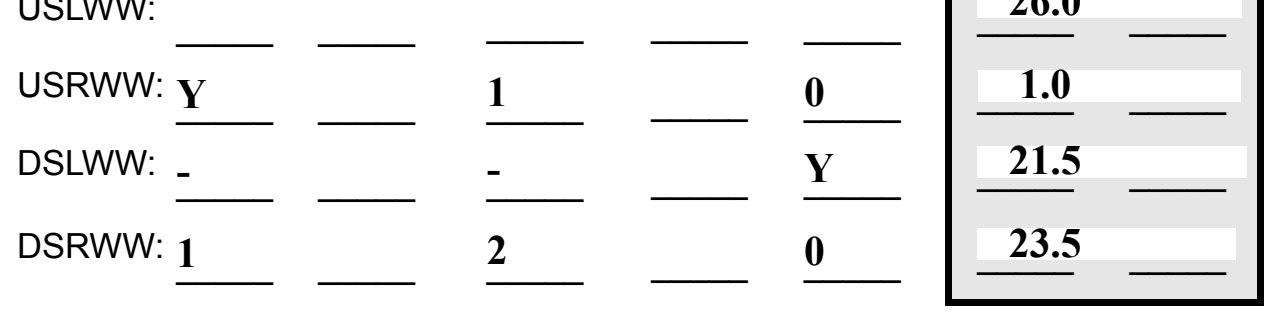

Wingwall materials: 1- Concrete; 2- Stone masonry or drywall; 3- steel or metal; 4- wood

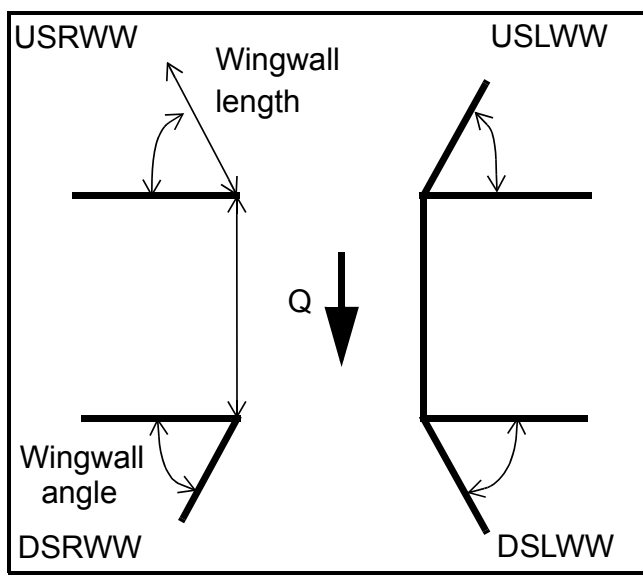

82. Bank / Bridge Protection:

\begin{tabular}{|l|l|l|l|l|l|l|l|c|}
\hline Location & USLWW & USRWW & LABUT & RABUT & LB & RB & DSLWW & DSRWW \\
\hline Type & $\mathbf{1}$ & $\mathbf{0}$ & $\mathbf{Y}$ & $\mathbf{0}$ & $\mathbf{1}$ & $\mathbf{1}$ & - & - \\
\hline Condition & $\mathbf{Y}$ & - & $\mathbf{1}$ & $\mathbf{2}$ & $\mathbf{1}$ & $\mathbf{2}$ & - & - \\
\hline Extent & $\mathbf{1}$ & - & $\mathbf{2}$ & $\mathbf{2}$ & $\mathbf{2}$ & $\mathbf{0}$ & $\mathbf{0}$ & - \\
\hline
\end{tabular}

Bank / Bridge protection types: 0- absent; 1- < 12 inches; 2- < 36 inches; 3- < 48 inches; 4- < 60 inches; 
83. Wingwall and protection comments (eg. undermined penetration, unusual scour processes, etc.):

-
-
-
-
-
-
-
-

\section{Piers:}

84. Are there piers? _ _ (Y or if $N$ type ctrl-n pr)

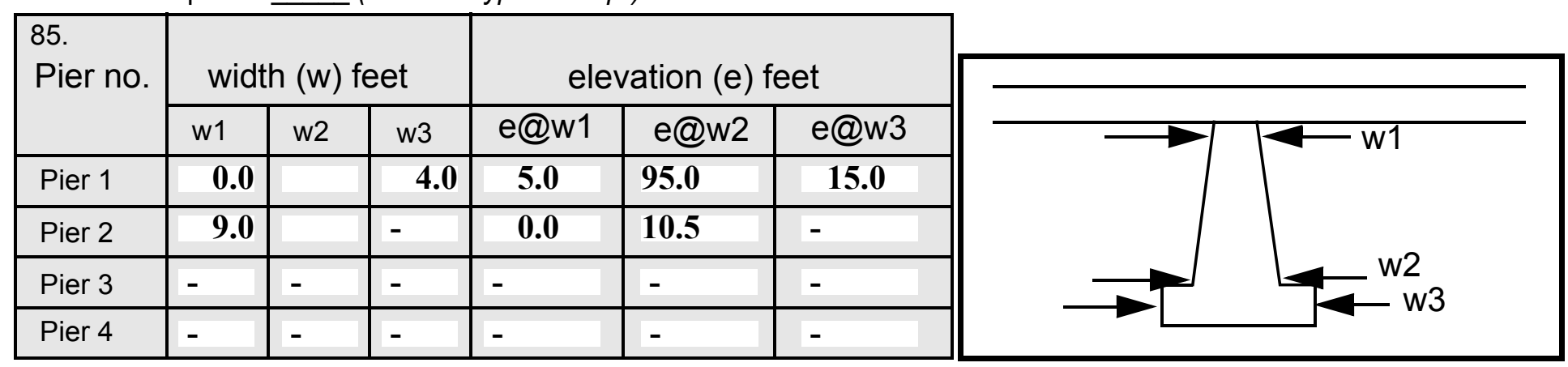

\begin{tabular}{|l|l|l|l|l|}
\hline Level 1 Pier Descr. & 1 & \multicolumn{1}{|c|}{2} & 3 & \multicolumn{1}{|c|}{} \\
\hline 86. Location (BF) & & - & - & - \\
\hline 87. Type & & - & - & - \\
\hline 88. Material & & - & - & - \\
\hline 89. Shape & & - & - & - \\
\hline 90. Inclined? & & - & - & - \\
\hline 91. Attack $\angle$ (BF) & & - & - & - \\
\hline 92. Pushed & & - & - & - \\
\hline 93. Length (feet) & - & - & - & - \\
\hline 94. \# of piles & & - & - & - \\
\hline 95. Cross-members & & - & - & - \\
\hline 96. Scour Condition & & - & - & - \\
\hline 97. Scour depth & $\mathbf{N}$ & - & - & - \\
\hline 98. Exposure depth & - & - & - & - \\
\hline
\end{tabular}

LFP, LTB, LB, MCL, MCM, MCR, RB, RTB, RFP

1- Solid pier, 2-column, 3- bent

1-Wood; 2-concrete; 3- metal; 4- stone

1- Round; 2- Square; 3- Pointed

Y-yes; $N$ - no

$L B$ or $R B$

0- none; 1- laterals; 2- diagonals; 3- both

0- not evident; 1- evident (comment);

2- footing exposed; 3- piling exposed;

4- undermined footing; 5- settled; 6- failed 
99. Pier comments (eg. undermined penetration, protection and protection extent, unusual scour processes, etc.):

-
-
-
-
-
-
-
-
-
-

100.

\section{E. Downstream Channel Assessment}

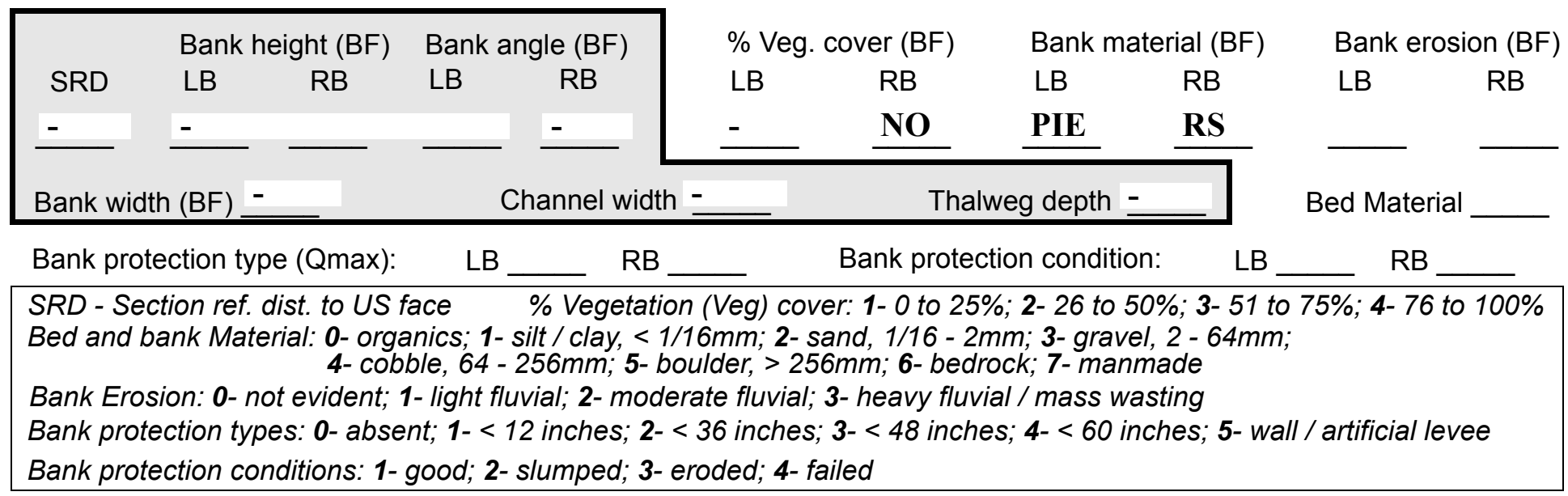

Comments (eg. bank material variation, minor inflows, protection extent, etc.):

4
3
543
543
2
1
543
0
0
-
-

The bed and banks consist of boulders, cobble and gravel.

101. Is a drop structure present? ___ ( $Y$ or $N$, if $N$ type ctrl-n ds) 102. Distance: ___ feet

103. Drop: ___ feet 104. Structure material:___ (1- steel sheet pile; 2- wood pile; 3- concrete; 4- other)

105. Drop structure comments (eg. downstream scour depth): 
106. Point/Side bar present? (Y or $N$. if $N$ type ctrl-n pb)Mid-bar distance: Mid-bar width:

Point bar extent: feet

(US, UB, DS) to $\underline{\mathbf{N}}$ feet (US, UB, DS

$D S)$ positioned \%LB to DR \%RB

Material: $\mathbf{O P}$

Point or side bar comments (Circle Point or Side; note additional bars, material variation, status, etc.):

\section{STRUCTURE}

Is a cut-bank present? (Y or if $N$ type ctrl- $n$ cb) Where? (LB or $R B)$

Mid-bank distance: $\underline{\mathbf{Y}}$ Cut bank extent: 120 feet $\underline{\mathbf{2 4}}$ (US, UB, DS) to $\underline{\mathbf{7 0}}$ feet $\underline{\mathrm{DS}}$ (US, UB, DS)

Bank damage: 190 (1- eroded and/or creep; 2- slip failure; 3- block failure)

Cut bank comments (eg. additional cut banks, protection condition, etc.):

DS

20

100

345

Is channel scour present? Thi (Y or if $N$ type ctrl-n cs) Mid-scour distance: $\underline{\mathbf{s}}$

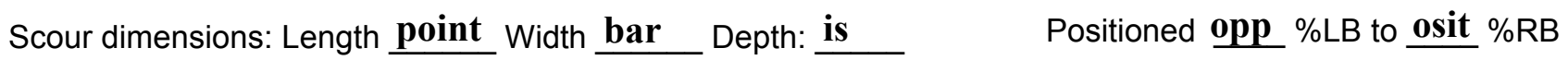

Scour comments (eg. additional scour areas, local scouring process, etc.):

e a severe cut bank on the DS left bank.

Are there major confluences? $\mathbf{Y}$ ( $Y$ or if $N$ type ctrl-n $m c)$

Confluence 1: Distance 100

Confluence 2: Distance $\underline{\mathbf{1 7 0}}$

How many? $\underline{\mathbf{L B}}$

Type DS (1- perennial; 2- ephemeral)

Type $\underline{2}$ (1- perennial; 2- ephemeral)

Confluence comments (eg. confluence name):

From $80 \mathrm{ft}$ to $170 \mathrm{ft}$ DS the cut bank is severe. The right bank is also cut from $10 \mathrm{ft}$ DS to $40 \mathrm{ft} \mathrm{DS}$ with a midbank distance of $25 \mathrm{ft}$. It is eroded.

\section{F. Geomorphic Channel Assessment}

107. Stage of reach evolution
1- Constructed

2- Stable

3- Aggraded

4- Degraded

5- Laterally unstable

6- Vertically and laterally unstable 
108. Evolution comments (Channel evolution not considering bridge effects; See HEC-20, Figure 1 for geomorphic descriptors):

Y

11

12

8

1

30

95

Scour is located at the DS end of the right abutment.

N 


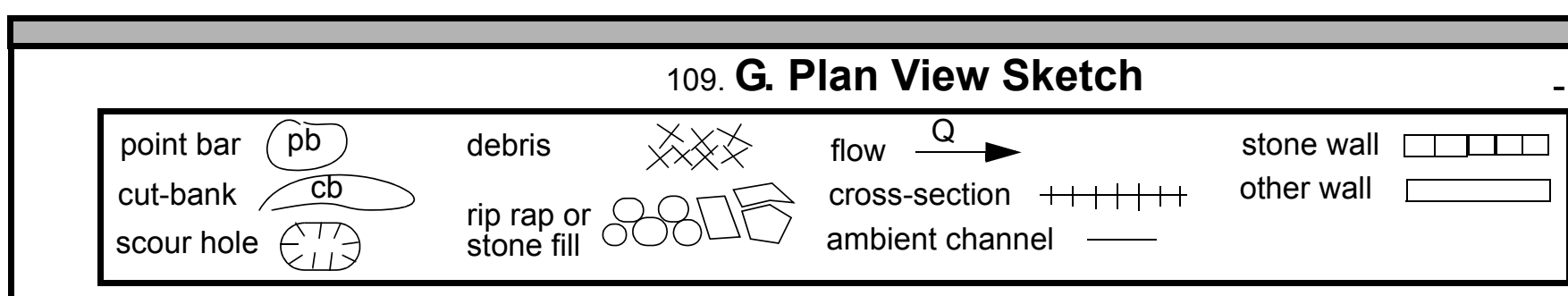


APPENDIX F:

SCOUR COMPUTATIONS 


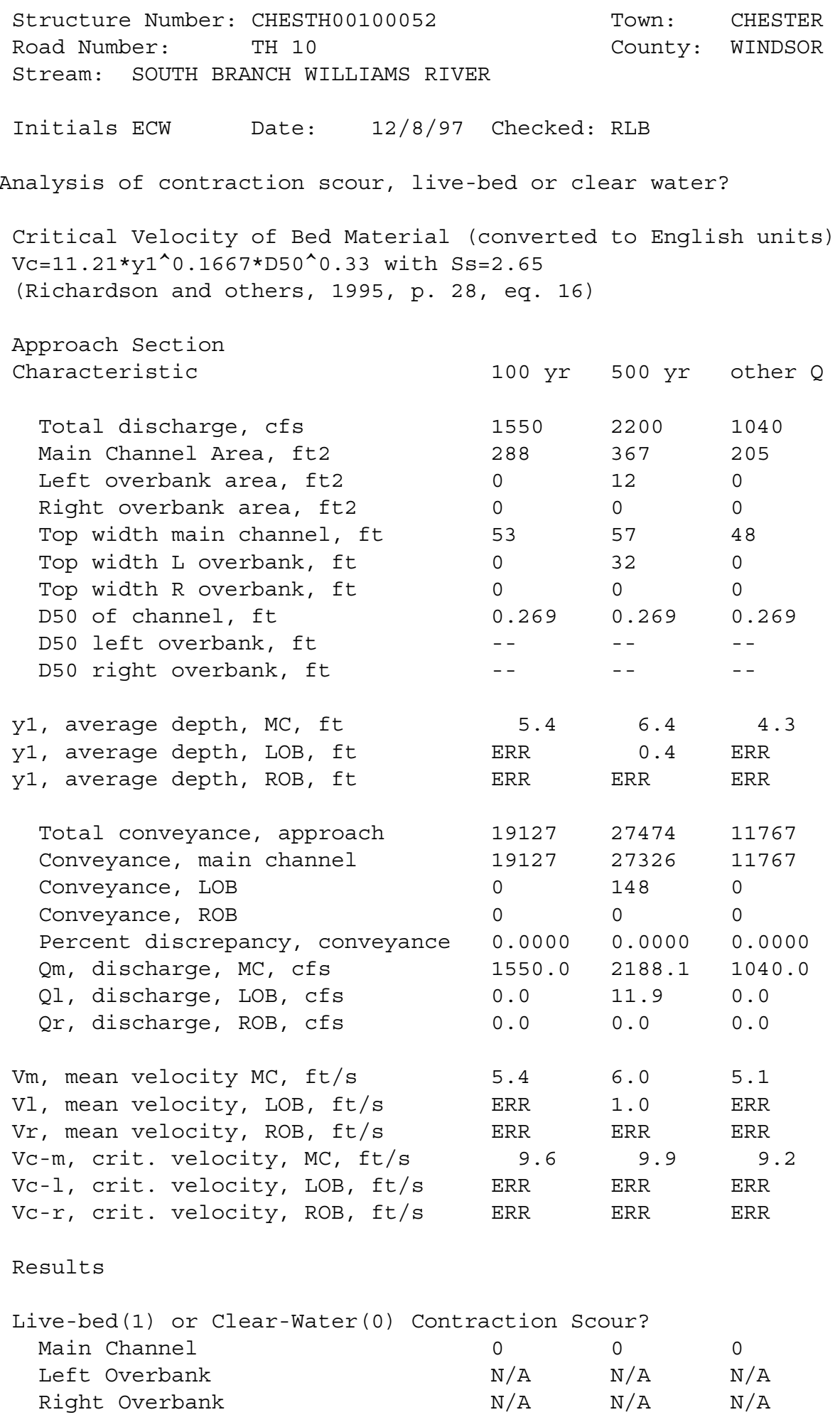


Clear water Contraction Scour in MAIN CHANNEL

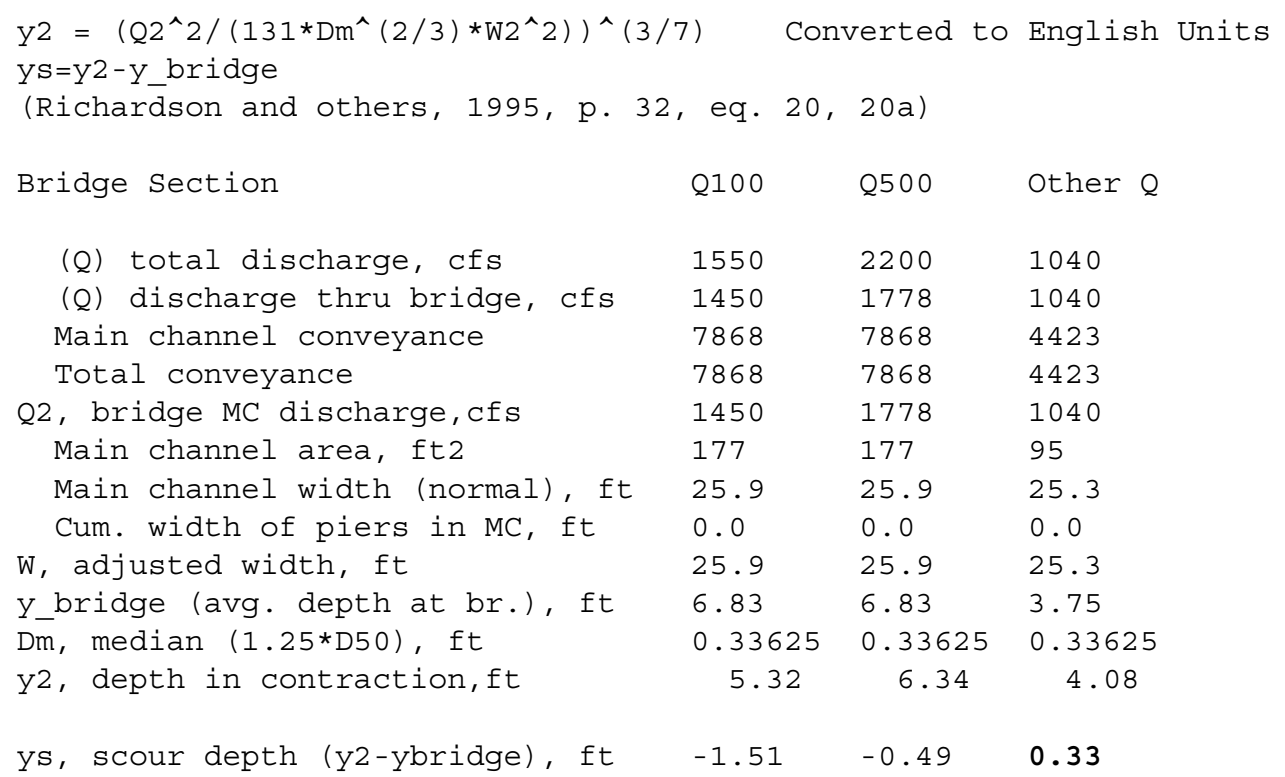

\begin{tabular}{|c|c|c|c|}
\hline \multicolumn{4}{|c|}{ Armoring } \\
\hline \multirow{2}{*}{\multicolumn{4}{|c|}{$\begin{array}{l}\mathrm{DC}=\left[\left(1.94 * \mathrm{~V}^{\wedge} 2\right) /(5.75 * \log (12.27 * \mathrm{y} / \mathrm{D} 90))^{\wedge} 2\right] /[0.03 *(165-62.4)] \\
\text { Depth to Armoring }=3 *(1 / \mathrm{PC}-1)\end{array}$}} \\
\hline & & & \\
\hline (Federal Highway Administration, 199 & $93)$ & & \\
\hline Downstream bridge face property & $100-y r$ & $500-y r$ & Other $Q$ \\
\hline Q, discharge thru bridge $M C$, cfs & 1450 & 1778 & 1040 \\
\hline Main channel area (DS), ft2 & 126 & 156 & 95 \\
\hline Main channel width (normal), ft & 25.9 & 25.9 & 25.3 \\
\hline Cum. width of piers, ft & 0.0 & 0.0 & 0.0 \\
\hline Adj. main channel width, ft & 25.9 & 25.9 & 25.3 \\
\hline D90, ft & 0.9026 & 0.9026 & 0.9026 \\
\hline D95, ft & 1.1138 & 1.1138 & 1.1138 \\
\hline Dc, critical grain size, ft & 0.7618 & 0.6766 & 0.7832 \\
\hline Pc, Decimal percent coarser than DC & 0.152 & 0.195 & 0.142 \\
\hline to armoring, ft & 12.75 & 8.38 & 14.20 \\
\hline
\end{tabular}




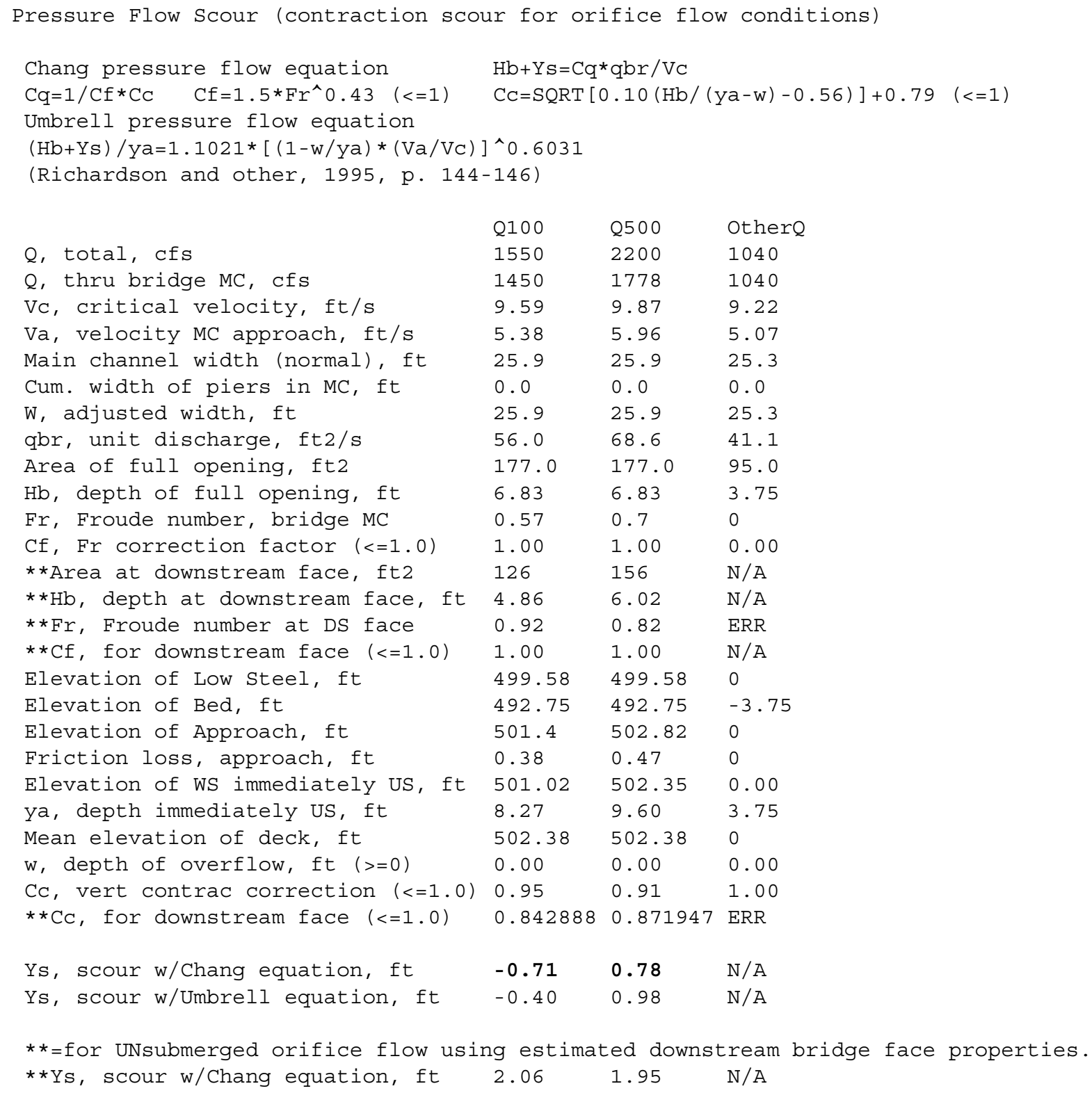




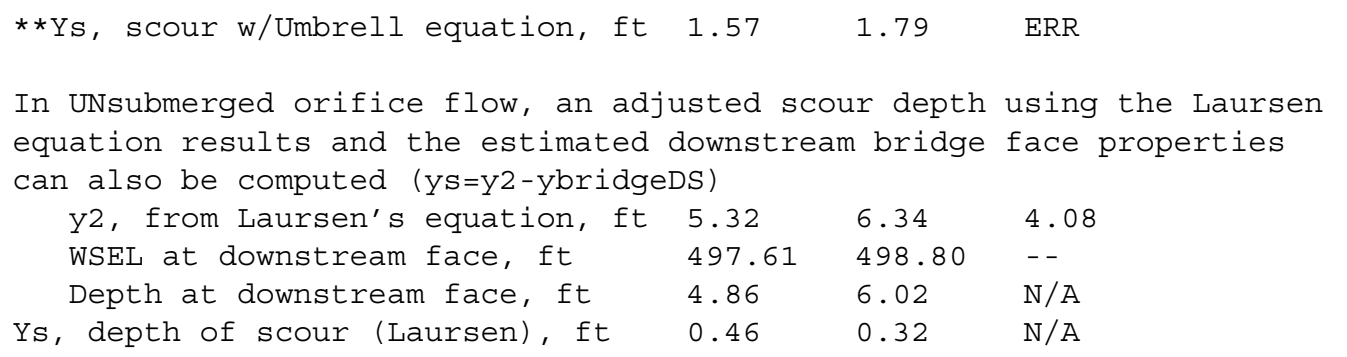

Abutment scour

Froehlich's Abutment Scour

$\mathrm{Ys} / \mathrm{Y} 1=2.27 * \mathrm{~K} 1 * \mathrm{~K} 2 *\left(\mathrm{a}^{\prime} / \mathrm{Y} 1\right)^{\wedge} 0.43 * \mathrm{Fr} 1 \wedge 0.61+1$

(Richardson and others, 1995, p. 48, eq. 28)

Characteristic

Left Abutment

Right Abutment

$100 \mathrm{yr} Q 500 \mathrm{yr} Q$ Other Q $100 \mathrm{yr}$ Q $500 \mathrm{yr} Q \mathrm{Other} Q$

(Qt), total discharge, Cfs $\quad 1550 \quad 2200 \quad 1040 \quad 1550 \quad 2200 \quad 1040$

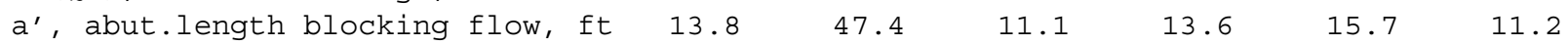

$\begin{array}{lllllll}\mathrm{Ae} \text {, area of blocked flow ft2 } & 41.39 & 69.95 & 24.63 & 50.81 & 60.1 & 39.5\end{array}$

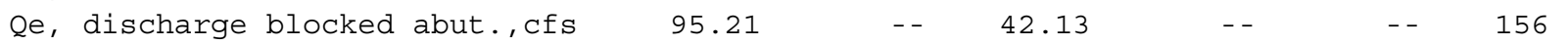

(If using Qtotal_overbank to obtain Ve, leave Qe blank and enter Ve and Fr manually)

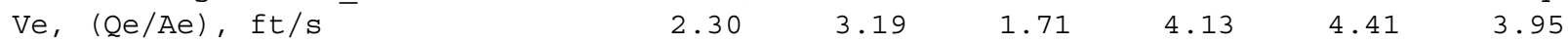

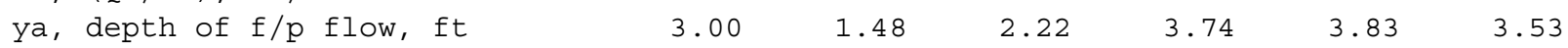

--Coeff., Kl, for abut. type (1.0, verti.; 0.82, verti. w/ wingwall; 0.55, spillthru)

$\begin{array}{llllllll}\mathrm{K} 1 & 0.82 & 0.82 & 0.82 & 0.82 & 0.82 & 0.82\end{array}$

--Angle (theta) of embankment (<90 if abut. points DS; >90 if abut. points US)

$\begin{array}{lllllll}\text { theta } & 70 & 70 & 70 & 110 & 110 & 110\end{array}$

$\begin{array}{lllllll}\text { K2 } & 0.97 & 0.97 & 0.97 & 1.03 & 1.03 & 1.03\end{array}$

Fr, froude number f/p flow $\quad \begin{array}{lllllll}0.234 & 0.448 & 0.202 & 0.349 & 0.344 & 0.371\end{array}$

$\begin{array}{lllllll}\text { ys, scour depth, ft } & 7.29 & 8.72 & 5.23 & 10.28 & 10.83 & 9.57\end{array}$

HIRE equation ( $a^{\prime} /$ ya $>25$ )

$\mathrm{Ys}=4 * \mathrm{Fr}^{\wedge} 0.33 * \mathrm{Y} 1 * \mathrm{~K} / 0.55$

(Richardson and others, 1995, p. 49, eq. 29) 


\begin{tabular}{|c|c|c|c|c|c|c|}
\hline$a^{\prime}$ (abut length blocked, ft) & 13.8 & 47.4 & 11.1 & 13.6 & 15.7 & 11.2 \\
\hline y1 (depth f/p flow, ft) & 3.00 & 1.48 & 2.22 & 3.74 & 3.83 & 3.53 \\
\hline$a^{\prime} / y^{\prime}$ & 4.60 & 32.12 & 5.00 & 3.64 & 4.10 & 3.18 \\
\hline Skew correction (p. 49, fig. 16) & 0.93 & 0.93 & 0.93 & 1.04 & 1.04 & 1.04 \\
\hline Froude no. f/p flow & 0.23 & 0.45 & 0.20 & 0.35 & 0.34 & 0.37 \\
\hline Ys w/ corr. factor K1/0.55: & & & & & & \\
\hline vertical & ERR & 7.66 & ERR & ERR & ERR & ERR \\
\hline vertical w/ ww's & ERR & 6.28 & ERR & ERR & ERR & ERR \\
\hline & ERR & 4.21 & ERR & ERR & ERR & ERR \\
\hline Abutment riprap Sizing & & & & & & \\
\hline Isbash Relationship & & & & & & \\
\hline $\mathrm{D} 50=\mathrm{Y}^{*} \mathrm{~K} * \mathrm{Fr}{ }^{\wedge} 2 /(\mathrm{Ss}-1)$ and $\mathrm{D} 50=\mathrm{Y}^{*} \mathrm{~K} *$ & $\wedge 2) \wedge 0$ & $(S S-1)$ & & & & \\
\hline (Richardson and others, 1995, p11 & eq. & & & & & \\
\hline Characteristic & Q100 & Q500 & Other $\mathrm{Q}$ & Q100 & Q500 & Other $\mathrm{Q}$ \\
\hline Fr, Froude Number & 0.92 & 0.82 & 1 & 0.92 & 0.82 & 1 \\
\hline$y$, depth of flow in bridge, ft & 4.86 & 6.02 & 3.75 & 4.86 & 6.02 & 3.75 \\
\hline Median stone Diameter for riprap & : left & utment & & right & abutment, & ft \\
\hline Fr< $<=0.8$ (vertical abut.) & ERR & ERR & ERR & $E R R$ & ERR & ERR \\
\hline Fr>0.8 (vertical abut.) & 1.99 & 2.38 & 1.57 & 1.99 & 2.38 & 1.57 \\
\hline
\end{tabular}

